\title{
COMMENTS
}

\section{Political Patronage in Public Contracting}

\author{
In Elrod v. Burns, ${ }^{1}$ the Supreme Court held that the discharge
} of a nonpolicymaking, nonconfidential public employee solely on the basis of his political affiliation violated the employee's first amendment rights of association and expression. The Court reaffirmed this holding in Branti v. Finkel, ${ }^{2}$ where it delineated the class of employees protected by its holding in Elrod to include all public employees except those for whom "party affiliation is an appropriate requirement for the effective performance of the public office involved." With these two decisions, the Court struck down an important part of the patronage system ${ }^{4}$-an institution that has played a prominent role in federal, state, and local government for over two hundred years. ${ }^{5}$

1427 U.S. 347 (1976).

2445 U.S. 507 (1980).

3 Id. at 518.

- The term "patronage" refers generally to "the allocation of the discretionary favors of government in exchange for political support." M. Tolchin \& S. Tolchin, To THE VICToR . . 5 (1971). Although patronage systems have traditionally centered around the distribution of government jobs, see, e.g., F. Soraur, Party Politics in America 82-85 (1968), the objects of patronage also include the awarding of government contracts, preferential treatment by executive agencies, improved public services, and even the approval of and site selection for public works projects subject to the control of legislators. M. ToLcHIN \& S. Tolchin, supra, at 5-6; see Elrod v. Burns, 427 U.S. at 353. Patronage is often associated with corruption in public office, M. Johnston, Political Corruption and Public Policy in AMERICA 176 (1982), and this image of the practice has led to reforms such as civil service laws in public employment and low-bid laws in public contracting. Policy arguments about the tendency of patronage to lead to corruption through such practices as bribes or kickbacks are not relevant to the constitutional inquiry at issue in the present discussion, see Elrod, 427 U.S. at 354, and this comment assumes that patronage is conducted in accordance with all other existing laws and that, aside from the constitutional objections to the practice discussed here, patronage is an unobjectionable method of increasing the resources at the disposal of political parties.

- Patronage was common even in the Washington administration, when Hamilton made a concerted effort to ensure that only Federalists were appointed to government posts. See C. Prince, The Federalists and the Origins of the U.S. Civil Service 2-6 (1977). The Jackson administration raised patronage to a high art, replacing large numbers of federal employees with loyal party supporters. M. Tolchin \& S. Tolchin, supra note 4, at 254. 
In three recent cases, ${ }^{6}$ the United States Courts of Appeals for the Seventh and Eighth Circuits held that the first amendment protection provided public employees in Elrod and Branti does not extend to government contractors. These holdings preserve one of the most highly valued elements of patronage systems, the distribution of government contracts as a means of rewarding loyal political supporters, from constitutional invalidity. Under these decisions, the first amendment rights of parties depend, in the face of patronage practices, on whether they work for government as employees or as independent contractors. ${ }^{7}$

This comment will examine the Seventh and Eighth Circuit "patronage contracting", decisions to determine whether they are sound in light of Elrod, Branti, and other Supreme Court decisions defining the scope of first amendment freedoms. Part I reviews the

While civil service statutes and the implementation of merit systems had caused the practice to decline in many jurisdictions prior to Elrod and Branti, patronage still flourished in many states, such as Pennsylvania, see F. SorAur, supra note 4, at 83 , and cities, such as Chicago, see M. Royko, Boss 17 (1971), and New York, see R. Caro, The Power Brokrr passim (1974). At the federal level, executive discretion to engage in patronage has been greatly curtailed in the employment context by the federal civil service system, see, e.g., 5 U.S.C. $\$ \S 7321-24$ (1982), and in public contracting by statutory competitive bidding requirements, 41 U.S.C. $\$ \S 252-53$ (1982). Many states also have similar laws restricting executive discretion to engage in patronage employment, see, e.g., ILL. ANN. STAT. ch. 24, §§ 38s38v (Smith-Hurd 1969 \& Supp. 1983); N.Y. Crv. SRRv. LAw $§ 107$ (McKinney 1983), or contracting, see, e.g., ILl. ANN. STAT. ch. 24, § 8-10-3 (Smith-Hurd Supp. 1983); N.Y. GzN. MuN. LAw $\S 103$ (McKinney Supp. 1983). Indeed, federal law prohibits political contributions by government contractors altogether. 2 U.S.C. \$ 441c (1982).

- LaFalce v. Houston, 712 F.2d 292 (7th Cir. 1983), cert. denied, 104 S. Ct. 712 (1984); Fox \& Co. v. Schoemehl, 671 F.2d 303 (8th Cir. 1982); Sweeney v. Bond, 669 F.2d 542 (8th Cir.), cert. denied, 103 S. Ct. 174 (1982).

The distinction between employees and independent contractors is a recurring one in the law, and determining into which category a particular individual falls is often difficult for the courts. See NLRB v. Hearst Publications, Inc., 322 U.S. 111, 120-22 (1944). At common law, for example, the distinction arises in determining vicarious liability for torts under the doctrine of respondeat superior. See Restatement (SEcond) of AGENcy §§ 2, 219, 250 (1958). The distinction also has legal significance where statutory rights apply only to employees. E.g., Civil Rights Act of 1964, tit. VII, $\$ \S 701$ (b), 703(a), 704, 42 U.S.C. $\$ \S 2000$ e(b), 2000e-2a, 2000e-3 (1982) (unlawful employment practices); National Labor Relations Act, $\$ \S$ 1, 2(2)-(3), 7, 8(a), 29 U.S.C. $\$ \$ 151,152(2)-(3), 157,158(a)$ (1982) (unfair labor practices). In constitutional jurisprudence, however, the distinction is rarely important. See, e.g., Lefkowitz v. Turley, 414 U.S. 70, $83-84$ (1973) (rejecting the distinction in striking down a statute for violating fifth amendment protection against self-incrimination); Lutcher v. Musicians Union Local 47, 633 F.2d 880 (9th Cir. 1980) (independent contractor's claim against school board for discriminating on the basis of religious affiliation fails under Title VII, since independent contractor not a statutory "employee," but is valid under the first amendment); cf. Fullilove v. Klutznick, 448 U.S. 448 (1980) (subjecting federal contracting program to equal protection scrutiny).

- The term "patronage contracting" will be used throughout this comment to refer to government contracting practices that are motivated by partisan political considerations. 
Supreme Court's patronage employment decisions and the patronage contracting decisions by the courts of appeals. Part II analyzes and compares the interests identified in these decisions in order to determine whether contractors can be meaningfully distinguished from employees for purposes of determining the constitutionality of patronage practices with respect to each. This Part demonstrates that no legally relevant distinction exists between employees and contractors in terms either of the government's interest in using patronage or of the employee or contractor's interest in free speech. The analysis suggests that, after Elrod and Branti, the case of contractors is an easy one. This conclusion, however, leaves unexplained the puzzling unanimity of seven judges on three panels in two circuits in reaching the opposite conclusion. Part III suggests that the reluctance of these judges to follow Elrod and Branti derives from a general reluctance of the judiciary to restructure established political institutions (as opposed to striking down particular results reached by political institutions) on the authority of the first amendment. This concern cuts to the very heart of established first amendment jurisprudence, and challenges the correctness of Elrod and Branti themselves. While this concern may be grounds for reconsidering these cases, it is not, the comment argues, grounds for drawing unprincipled distinctions such as that drawn between employees and contractors. Thus, the comment concludes, until such time as Elrod and Branti are to be reconsidered, their rationale requires that the same protection be accorded to government contractors as to government employees.

\section{The Patronage Decisions}

\section{A. The Supreme Court Employment Decisions}

1. Elrod v. Burns. In Elrod v. Burns, ${ }^{9}$ employees of the Cook County, Illinois, Sheriff's Office were discharged by the newly elected Democratic Sheriff in order to make room for supporters of the Democratic Party. These employees, hired by the previous Republican administration, would have been permitted to retain their positions only if they had pledged political allegiance to the Democratic party, promised to work for the election of Democratic candidates, or contributed a portion of their wages to the party..$^{10}$ In a 5-3 decision, but without an opinion for the majority, ${ }^{11}$ the Court

- 427 U.S. 347 (1976).

$10 \mathrm{Id}$. at 355.

11 Justice Brennan wrote the plurality opinion, which was joined by Justices White and Marshall. Id. at 349. Justice Stewart's separate concurring opinion was joined by Justice 
held that the discharges violated the first amendment. The plurality found that two first amendment interests were implicated: the interest of the government employee in freely expressing his own political beliefs and freely associating with others in order to advance those beliefs, ${ }^{12}$ and the interest of society in the free and open discussion of public affairs. ${ }^{13}$ Although the plurality opinion failed to separate these two interests clearly, both were important to its decision.

In addressing the effect of patronage discharges on the individual employee's interests in freedom of speech and association, the plurality emphasized the difficult choice such a practice leaves to the average public employee: he can freely advocate his true political beliefs only at the cost of losing his job. ${ }^{14}$ Since the practice induces employees to advocate the views of another party to the

Blackmun. Id. at 374. Dissenting opinions were filed by Justice Powell, id. at 376, and Chief Justice Burger, id. at 375. Justice Rehnquist joined Justice Powell's dissent, as did the Chief Justice. Justice Stevens did not participate in the decision.

12 Id. at 355-56.

1s Id. at 356-57.

${ }^{34}$ In response to the argument that the employee remains free to support the party of his choice and is constrained only insofar as he must support the incumbent party as well, the plurality pointed out that "the average public employee is hardly in the financial position to support his party and another." 427 U.S. at 355 . In this context, it should be noted that the right of free expression and association includes the right not to speak or associate. In Wooley v. Maynard, 430 U.S. 705 (1977), the Court held that "the right of freedom of thought protected by the First Amendment . . . includes both the right to speak freely and the right to refrain from speaking at all. [These] are complementary components of the broader concept of 'individual freedom of mind.' " Id. at 714 (quoting West Va. State Bd. of Educ. v. Barnette, 319 U.S. 624,637 (1943)). The Court has invalidated a number of laws on the basis of this premise. E.g., Miami Herald Publishing Co. v. Tornillo, 418 U.S. 241, 256 (1974) (striking down law requiring newspapers to give political candidates equal space to answer criticism by the newspaper); West Va. State Bd. of Educ. v. Barnette, 319 U.S. 624, 633-34 (1943) (striking down law requiring children to salute the flag). See generally Gaebler, First Amendment Protection Against Government Compelled Expression and Association, 23 B.C.L. REv. 995 (1982).

In Abood v. Detroit Bd. of Educ., 431 U.S. 209 (1977), the Court extended protection from compelled expression to compelled contributions of money, invalidating a statute requiring government employees, as a condition of employment, to pay the union a service charge equal to union dues. The Court found "meritorious" the argument that this statute unconstitutionally prevented the employees "from refusing to associate[, insofar as the union spends] a part of their required service fees to contribute to political candidates and to express political views." Id. at 234. Relying on Buckley v. Valeo, 424 U.S. 1 (1976) (per curiam), for the proposition that contributing to an organization for the purpose of spreading a political message is protected by the first amendment, the Court concluded that " $t]$ he fact that the appellants are compelled to make, rather than prohibited from making, contributions for political purposes works no less an infringement of their constitutional rights." 431 U.S. at 234. 
detriment of their own views, the result was "tantamount to coerced belief."15

Intermingled with the plurality's discussion of the effect of patronage dismissals on the individual employee's interests in freedom of belief and association was a concern for the effect of patronage employment practices on the political process. The Court reasoned that patronage interferes with the " uninhibited, robust, and wide-open'" discussion of public affairs ${ }^{16}$ by making public employment an inducement for suppressing the expression of one's true beliefs. ${ }^{17}$ As such, patronage violates the fundamental first amendment interest in free " "[c]ompetition in ideas and governmental policies ... a the core of our electoral process" "18 by coercing opinion to favor one party. The result is to give the incumbent party an advantage in the electoral process, perhaps even a substantial one, by starving its political opposition. ${ }^{19}$

The plurality next examined whether patronage advanced any governmental interests that might justify this interference with the employee's first amendment interests. Treating the problem as one involving a content-based restriction on speech, ${ }^{20}$ the plurality ap-

1s Elrod, 427 U.S. at 355 (citing Buckley v. Valeo, 424 U.S. 1, 19 (1976) (per curiam)). The plurality found that, as a result of this coercion, patronage dismissals were a means for government to produce a result it could not command directly. Id. at 358-59. The plurality relied on Keyishian v. Board of Regents, 385 U.S. 589 (1967) (invalidating New York law denying employment to any teacher who has been a member of the Communist party), and Perry v. Sindermann, 408 U.S. 593 (1972) (refusal to renew a contract, due to criticism of the administration, violates first amendment), as authority for the proposition. The plurality went on to reject the argument that government employment was a privilege and not a right, and therefore could be subjected to any conditions, however unreasonable. This "right/privilege" distinction, the plurality noted, had long been rejected by the Court and no longer provide a basis for determining the scope of a constitutional right. 427 U.S. at 360-61 (citing Sugarman v. Dougall, 413 U.S. 634, 644 (1973); Graham v. Richardson, 403 U.S. 365, 374 (1971); Sherbert v. Verner, 374 U.S. 398, 404 (1963)); see also infra notes 122-25 and accompanying text (right/privilege distinction generally rejected in first amendment jurisprudence).

18 427 U.S. at 357 (quoting New York Times Co. v. Sullivan, 376 U.S. 254, 270 (1964)). The concern expressed by the plurality is that of distortion of the marketplace of ideas. The plurality contended that insofar as patronage increased total speech, it did so by coercion and in favor of one view or party to the exclusion of others. This the plurality deemed inimical to the first amendment search for truth in a wide-open marketplace of ideas.

${ }^{17} I d$. at 356-58.

18 Id. at 357 (quoting Williams v. Rhodes, 393 U.S. 23, 32 (1968)).

10 The plurality stated that "where the practice's scope is substantial relative to the size of the electorate, the impact on the process can be significant." Id. at 356.

so A content-neutral restriction such as a restriction on the time, place, or manner in which the right to speak may be exercised, does not regulate speech on the basis of the speech's message. The Court applies a less severe standard in reviewing content-neutral restrictions. Stone, Content Regulation and the First Amendment, 25 WM. \& MARY L. REv. 189, 190-93 (1983). Patronage practices involve content-based restrictions. See infra notes $113,116$. 
plied the "firmly-established" first amendment version of strict scrutiny, ${ }^{21}$ which requires that the challenged practice "further some vital government end by a means that is least restrictive of freedom of belief and association in achieving that end."22 Under this standard, the plurality found the governmental interests served by patronage to be either insufficient or achievable by alternatives less restrictive than a patronage system. ${ }^{23}$

Finally, the plurality rejected the argument that patronage furthers first amendment concerns and is vital to the democratic process because it stimulates public discussion of political issues by increasing participation in partisan politics. ${ }^{24}$ In rejecting this argument, the plurality stressed two points. First, whatever first amendment interest patronage serves, it does so only by coercing individuals. ${ }^{25}$ Second, even if patronage contributes to the public discussion of ideas, it does so at the expense of suppressing other ideas at the same time. ${ }^{28}$ Although the volume of public discussion may be increased, the resulting discussion is not "uninhibited, robust, and wide-open."

12427 U.S. at $362-63$ (citations omitted).

22 Id. at 363 .

2s The argument that patronage increases governmental efficiency was rejected because "[t]he inefficiency [resulting from wholesale replacements] every time political office changes hands belies this justification." Id. at 364. Of course, it might well be that politically motivated employees with a stake in the enterprise learn their jobs more quickly and perform their jobs more efficiently. However, the plurality pointed out that job capability is generally not a consideration in determining whom to hire under a patronage system; the main consideration is service to the party. Id. at 364-65. In any event, the plurality argued, one cannot infer that an employee will perform his job less effectively merely because of a difference in party affiliation. Moreover, less restrictive means, such as discharging the employee upon a showing of poor performance, are available to further the end of efficient government. Id. at 365-66.

The plurality also rejected the contention that patronage was justified by the need to ensure the accountability of the government to the public, $i d$. at 366 , and found that the need of the elected party for loyal employees did not justify wholesale patronage discharges, id. A less restrictive alternative was available for this latter purpose as well: limiting patronage dismissals to policymaking employees "to the end that representative government not be undercut by tactics obstructing the implementation of policies . . . presumably sanctioned by the electorate." Id. at 367.

24 Id. at 368-73.

23 Id. at $369-70$.

28 Id. at 369.

${ }^{27}$ Id. The plurality explained that while parties are themselves engaged in an activity central to the first amendment, they have survived even in the absence of patronage, and that the practice harms the democratic process as much as it aids it by entrenching "one or a few parties to the exclusion of others." Id. In the final analysis, the plurality stated, the first amendment is intended to protect " $a$ democratic system . . . indispensibly dependent on the unfettered judgment of each citizen on matters of political concern." Id. at 372. Accordingly, any contribution made by patronage dismissals to the democratic process is out- 
Justice Stewart, joined by Justice Blackmun, concurred in the judgment but refused to join in the plurality's "wide-ranging opinion," 28 fearing that its broad language might be applied to patronage practices beyond employee dismissals. Without elaboration, Justice Stewart limited his opinion, and thereby the Court's holding, ${ }^{29}$ to "[t]he single substantive question .... whether a nonpolicymaking, nonconfidential government employee can be discharged . . . from a job that he is satisfactorily performing upon the sole ground of his political beliefs." ${ }^{30}$ Justice Stewart agreed that he could not. ${ }^{31}$

Justice Powell, arguing that the Court was "unnecessarily constitutionaliz[ing] another element of American life,"32 disagreed with the plurality on all counts. He began by stressing the long history of patronage as a part of American politics. ${ }^{33}$ Justice Powell then evaluated, in light of that history, the governmental interests at stake in patronage practices. First, "by providing incentives to take part in [the political] process," patronage has "increas[ed] the volume of political discourse in society," and so contributed to "democratizing American politics." 34 Second, patronage increases government accountability and responsibility to the electorate by closely identifying the party in power with the government. ${ }^{35}$ Finally, and perhaps most importantly in Justice Powell's view, patronage leads to stronger and more stable political parties at the state and local levels by increasing the number of active members in party organizations. ${ }^{36}$

weighed by the harm to first amendment interests that results from the coercion of individuals and the distortion of the marketplace of ideas. Id. at 372-73.

${ }^{28}$ Id. at 374.

29 Under the principle of Marks v. United States, 430 U.S. 188, 193 (1977), where there is no clear majority opinion, the opinion necessary to form a majority and which most narrowly extends existing law governs. Thus, this concurrence expresses the "holding" of Elrod. See, e.g., Stegmaier v. Trammell, 597 F.2d 1027, 1034 (5th Cir. 1979). After Branti, the point is academic. See infra notes $42-57$ and accompanying text.

so 427 U.S. at 375 .

s1 Id.

32 Id. at 389. He was joined by Chief Justice Burger and Justice Rehnquist.

ss Id. at $377-80$. He pointed out that the practice was common as early as the Washington Administration. Id. at 378.

34 Id. at 379 (citing C. Fish, The Crvi. Service and the Patronage 156-57 (1905); Sorauf, Patronage and Party, 3 Minwest J. Pol. Sci. 115-16 (1959)).

3s Id. at 382. Taking exception to the plurality's view that the two-party system was not the sine qua non of the democratic process, Justice Powell believed that such a system was essential to preventing "'unrestrained factionalism," "id. at 383 (quoting Storer v. Brown, 415 U.S. 724, 735 (1974)), and providing the electorate "a guidepost by which [to] rationalize a myriad of political choices," id. at 385 .

se Id. at 384-85. 
Justice Powell de-emphasized the infringement of first amendment interests caused by patronage dismissals. He argued that "the system leaves significant room for individual political expression[, since e]mployees . . . may vote freely and express themselves on some political issues." ${ }^{37}$ Justice Powell was not greatly disturbed by the possibility that patronage might suppress public discussion. He saw the conflict, at least at the local level, as one between increased discussion of public affairs under a system of patronage, and little or no discussion at all without it, and he contended that the gains to political debate brought about by patronage were worth the cost of coercing individuals to support a party ${ }^{38}$ At the very least, he stated, since this was not a case of "an attempt to exclude 'a minority group . . . odious to the majority," "39 the question of the effect of patronage on the political system was one for the legislatures, and not the courts, to resolve. ${ }^{40}$

Because there was no clear majority opinion in Elrod, the scope of the Court's decision was in doubt. The least that the case stood for was that the first amendment prohibited dismissals of nonpolicymaking, nonconfidential government employees solely on the basis of their partisan political affiliations. ${ }^{41}$ Since a majority of the Court refused to endorse the rationale of the plurality opinion, the validity of other patronage practices remained in doubt.

2. Branti v. Finkel. When a new Democratic public defender took office in Rockland County, New York, he refused to reappoint two assistant public defenders who had served under the previous Republican public defender solely because of their political affiliations. In a 6-3 decision, the Court held that the disappointed employees' first amendment rights had been violated. ${ }^{42}$

37 Id. at 388 (footnote and citations omitted).

ss Id. at 385-88.

39 Id. at 387 (quoting Garner v. Board of Public Works, 341 U.S. 716, 725 (1951)).

s0 Id. at 386. The plurality rejected the notion that judgments as to the propriety of particular patronage practices were best left to legislatures when it rejected defendant's arguments that the separation of powers and the political questions doctrines precluded judicial invalidation of patronage dismissals. Id. at 351-53. The plurality's rationales for rejecting these arguments were that a state is not a coordinate branch of the federal government, and that the case involved "a question of constitutional interpretation, a function ultimately the responsibility of this Court." Id. at 352 (citations omitted). As this comment will suggest in Part III, see infra notes 151-67 and accompanying text, the plurality may well have missed the gist of the defendant's argument, since lurking beneath that argument may be fundamental concerns about the legitimacy of judicial interference with the institutional structure of the democratic process.

4 See supra notes 28-31 and accompanying text.

42 Branti v. Finkel, 445 U.S. 507 (1980). The majority opinion was delivered by Justice Stevens. Justice Powell, joined by Justice Rehnquist, and joined in part by Justice Stewart, 
As in Elrod, the Court limited its holding to "the dismissal of public employees for partisan reasons."43 The Court did not expressly embrace the reasoning of the Elrod plurality, although it made clear its adherence to the holding in that case. ${ }^{44}$ Yet, in finding that the refusal to reappoint the two assistant public defenders violated the first amendment, the Branti majority's reasoning closely paralleled that of the Elrod plurality. ${ }^{45}$ Like the Elrod plurality, the Court emphasized the first amendment interests of the employees in freedom of belief and association. ${ }^{46}$ The Court also discussed what it labeled as a "separate but interrelated reason[]" found in the Elrod plurality's opinion-that government may not impose an unconstitutional condition on the receipt of a public benefit-and relied on this reason, too, to support its holding in Branti. ${ }^{47}$

Having reaffirmed the narrow holding ${ }^{48}$ of, and implicitly accepted at least part of the plurality's rationale in, Elrod, the Court proceeded to reevaluate the exception, recognized by a majority of the Court in Elrod, ${ }^{49}$ for policymaking or confidential employees. ${ }^{50}$ Finding that classifying employees as "policymaking" or "confidential" did not necessarily correlate with the first amendment and government interests involved, the Court changed the inquiry to whether "party affiliation is an appropriate requirement for effective performance of the public office involved."51 Applying this test to public defenders, the Court found that such officers did not fall within the newly delineated exception. ${ }^{.2}$ By focusing its attention only on those portions of the Elrod plurality's opinion that concern the coercive effects of patronage on the individual employee, the Branti Court failed to address the conflict between the Elrod plurality's assertion that government cannot stimulate the volume of

dissented. Justice Stewart also wrote a separate dissenting opinion.

is Id. at 513 n.7.

14 Id. at 512 n.6.

45 The Court declined to distinguish the two cases on the factual ground that the employees in Branti had not been coerced into supporting the new party in power: unlike the employees in Elrod, they were not given the choice of switching allegiances but had merely been dismissed. It was sufficient, the Court held, that the employees had shown that they were discharged because they belonged to the wrong political party. To hold otherwise "would surely emasculate the principles set forth in Elrod." Id. at 516.

16 Id. at 513-14; see supra notes 12-15 and accompanying text.

47 Id. at 513-16.

48 See supra note 28 and accompanying text.

4. Elrod, 427 U.S. at 367 (plurality opinion), 375 (Stewart, J., concurring).

so Branti, 445 U.S. at 517.

${ }^{51}$ Id. at 518 .

${ }^{62}$ Id. at $519-20$. 
public discussion at the cost of suppressing the views of certain individuals and Justice Powell's notion that the increase in public discussion of political affairs caused by patronage is well worth that cost. ${ }^{58}$ The majority opinion makes clear, however, that the individual employee's right to formulate his views on political issues free from government interference merits first amendment protection even though that protection may curtail the discretion of elected officials in making hiring and firing decisions.

Justice Powell again dissented. In addition to repeating many of the arguments from his dissent in Elrod, he criticized the Court's new standard as "framed in vague and sweeping language certain to create vast uncertainty." As a result, Powell argued, executive and legislative officials would often be unable to determine beforehand whether or not they could fill positions on the basis of political considerations. ${ }^{55}$ Powell expressed his concern that, as an institutional matter, it was improper for the Court to impose judicial restrictions on the freedom of the electorate to structure a system of self-government ${ }^{58}$ and on the ability of executive officials to "govern effectively and ... carry out new policies."

\section{B. The Patronage Contracting Decisions of the Courts of Appeals}

It was not long after Branti that disappointed public contractors began to seek the first amendment protection from patronage enjoyed by public employees. ${ }^{58}$ In Sweeney $v$. Bond, ${ }^{58}$ former fee

Bs In a footnote, the Branti Court intimated its acceptance of the view of the Elrod plurality on the public discussion issue, pointing out that, because patronage skews the balance of public discussion in favor of the party in power and thus "distort[s] the electoral process," patronage indirectly affects "the formation and expression of political beliefs." Id. at $514 \mathrm{n} .8$.

34 Id. at 524. Justice Powell also argued that the Court was expanding the class of government employees protected from patronage discharge, $i d$. at 522 , and was extending the protection to patronage hirings as well as dismissals, despite its explicit statement to the contrary, id. at 522 n.2.

so In Branti, for example, the law permitted the public defender, himself chosen by the county legislature, to appoint assistant public defenders. Justice Powell feared that after Branti the only way in which to fill government positions in accordance with the will of the electorate would be to make them elective. Id. at 532-34.

se Id. at 534 .

s7 Id. at 530 .

ss The application of Elrod and Branti to patronage hirings as well as patronage dismissals is uncertain, since the Supreme Court expressly avoided comment on this issue. See Branti, 445 U.S. at 513 n.7. The lower courts have generally applied Elrod and Branti to hirings. See, e.g., Cullen v. New York State Civil Serv. Comm'n, 435 F. Supp. 546, 550-52 (E.D.N.Y.) (condition on employment that employees pledge one percent of their salaries to the local Republican Party found unconstitutional under Elrod), appeal dismissed, 566 F.2d 


\section{agents for the Missouri Department of Revenue brought an action against the new Republican governor and the director of the De-}

846 (2d Cir. 1977); Harris v. Conradi, 675 F.2d 1212, 1217 (11th Cir. 1982) (dictum) (Branti applies to hiring); Rosenthal v. Rizzo, 555 F.2d 390, 392 (3d Cir.) (dictum) (Elrod extends to hirings), cert. denied, 434 U.S. 892 (1977); Aufiero v. Clarke, 489 F. Supp. 650, 654 (D. Mass. 1980) (dictum) (no distinction between patronage hiring and firing), aff'd, 639 F.2d 49 (1st Cir.), cert. denied, 452 U.S. 917 (1981); see also Comment, First Amendment Limitations on Patronage Employment Practices, 49 U. CHI. L. REv. 181, 200-02 (1982) (arguing that patronage hirings are unconstitutional under Elrod and Branti). A few courts have argued that hirings are not protected, although in no decided case has a prospective employee been denied relief after proving that he was denied employment for purely political reasons. See, e.g., Mazus v. Department of Transp., 629 F.2d 870, 873 (3d Cir. 1980) (dictum) (no evidence of political affiliation was considered, so issue was not reached, though the court took the opportunity to question its prior dictum in Rosenthal v. Rizzo), cert. denied, 449 U.S. 1126 (1981); Delong v. United States, 621 F.2d 618, 623-24 (4th Cir. 1980) (restricting relief under Elrod and Branti to employment decisions "substantial[ly] equivalent" to outright dismissal).

As a constitutional matter, there is no reason to deny hirings protection similar to that accorded firings. The Court has not regarded the distinction between vested rights and expectations as significant where first amendment rights are at stake, see, e.g., Sherbert v. Verner, 374 U.S. 398, 404-06 (1963); Speiser v. Randall, 357 U.S. 513, 518-20 (1958), although the distinction is relevant to defining whether a party has a liberty or property interest for purposes of the due process clause of the fourteenth amendment. Compare Board of Regents v. Roth, 408 U.S. 564, 576-78 (1972) (unilateral expectation of teaching job creates no property interest), and Greenholtz v. Inmates of Neb. Penal \& Correctional Complex, 442 U.S. 1, 8-11 (1979) (hope of obtaining parole is merely an expectancy and not a due process liberty interest), with Perry v. Sindermann, 408 U.S. 593, 599-603 (1972) (de facto tenure system may create a property interest), and Morrissey v. Brewer, 408 U.S. 471, 48182 (1972) (revocation of parole is a protected liberty interest). It would seem rather anomalous to accord an employee who was hired on the basis of political affiliation when his party was "in" greater protection than the would-be employee who was never hired because he did not choose to associate with any party.

There is, however, a more compelling reason not to distinguish between hirings and firings. Requiring party affiliation for employment, like denying employment for lack of party affiliation, imposes an unconstitutional condition on the exercise of the potential employee's right of association. The applicability of the doctrine of unconstitutional conditions does not depend on the individual's status, but focuses solely on the deterrent effect of the condition on the exercise of constitutional rights. See Comment, supra, at $196 \& \mathrm{n} .103$. The first amendment is concerned with protecting the individual's freedom to hold beliefs and to associate with others and the public interest in free and open debate, and not with distinctions between vested interests and mere expectancies. The status of the affected individual is material only to the extent that it provides government with greater leverage to suppress speech. See id. at 194-95. Especially in times of high unemployment, the lure of a government job can be very effective for this purpose. See The Supreme Court, 1975 Term, 90 HARv. L. REv. 1, 195 (1976).

Differences in the ease of proving and enforcing the rights of prospective and discharged employees provide a colorable basis for distinguishing the two in patronage employment. The added problems of proof and enforcement attendant upon extending the rights recognized in Elrod and Branti to disappointed applicants as well as dismissed former jobholders loom particularly large in the context of patronage contracting, since most affected contractors will be disappointed bidders, not discharged contractors. This enforcement issue is considered infra notes $137-50$ and accompanying text.

s9 669 F.2d 542 (8th Cir.), cert. denied, 103 S. Ct. 174 (1982). 
partment claiming that they had been unlawfully discharged from their positions solely on the basis of their political affiliation. The Eighth Circuit rejected, on two grounds, the claim that the former fee agents' first amendment rights had been violated. First, the court examined the nature of the plaintiffs' positions and found them to be independent contractors rather than state employees. ${ }^{60}$ Relying solely on the statements in Elrod and Branti limiting those decisions to the issue of discharged public employees, the court declined to extend first amendment protection to public contractors. ${ }^{61}$ Second, the court found that political affiliation was an appropriate requirement for the effective performance of the position, thus bringing the fee agents within the Branti exception. ${ }^{62}$

Shortly after the Sweeney decision, the Eighth Circuit reaffirmed its decision in that case in Fox \& Co. v. Schoemehl. ${ }^{63} \mathrm{~A}$ public accounting firm brought suit against the new mayor of St. Louis, alleging that it had been replaced as auditor for the St. Louis Board of Education solely because it had not supported the mayor in the recent election. In a very brief opinion, the Eighth Circuit denied relief, relying on Sweeney as authority for distinguishing employees from contractors in applying Elrod and Branti, and finding that there was no dispute about the plaintiff's status as an independent contractor. ${ }^{64}$ The court therefore found it unnecessary to ask whether political affiliation was necessary to the effec-

6669 F.2d at 545-46. Fee agents issue motor vehicle licenses and collect motor vehicle sales and use taxes for the state. See id. at 544 n.3. The court, noting that fee agents are not supervised by the state, are not paid by the state, and are considered to be self-employed for tax purposes, concluded that fee agents are independent contractors. See id. at 545-46.

11 Id. at 545 (citing Branti, 445 U.S. at 508; Elrod, 427 U.S. at 353).

${ }^{62} 669$ F.2d at 546. The court argued that fee agents are " 'selected emissaries of the incumbent administration and ... symbols of the governor's office who do not bring the usual disadvantages of patronage employees to their posts." "Id. (quoting the opinion of the trial court, 519 F. Supp. 124, 129 (E.D. Mo. 1981)). It is difficult to see how political affiliation is any more necessary to the effective collection of motor vehicle sales and use taxes than it is to the effective performance of the functions of the process server in Elrod or the assistant public defenders in Branti. The court seems to have misread the Branti exception as allowing patronage hiring unless partisan politics would hinder job performance rather than as allowing patronage hiring only when partisan political affiliation is necessary to job performance. Cf. United States Civil Serv. Comm'n v. National Ass'n of Letter Carriers, 413 U.S. 548 (1973) (upholding provision in Hatch Act, 5 U.S.C. \& 7324(a)(2) (1982), prohibiting political activity by federal employees because such activity is detrimental to the efficient administration of government). In its subsequent decision in Fox \& Co. v. Schoemehl, 671 F.2d 303 (8th Cir. 1982), however, the Eighth Circuit abandoned such arguments, relying exclusively on the distinction between employees and contractors. See infra notes 63-64 and accompanying text.

${ }^{83} 671$ F.2d 303 (8th Cir. 1982).

ot Id. at 305 . 
tive performance of the plaintiff's position as auditor for the school board.

The most recent case to address the constitutionality of patronage in public contracting is LaFalce v.-Houston. ${ }^{65}$ The plaintiff, an individual proprietor, had submitted the low bid for the installation and maintenance of benches along the streets of Springfield, Illinois; the contract was nevertheless awarded by the City of Springfield to a political supporter of the mayor. Although it recognized that the practice of awarding public contracts on political grounds undoubtedly inhibited free expression and association by contractors, the Seventh Circuit nevertheless rejected the plaintiff's claim, declining to extend the scope of Elrod and Branti to government contractors.

Unlike the courts in Sweeny and Fox \& Co., the LaFalce court examined the competing interests of the City and the contractor in an effort to draw a principled line between public employees and independent contractors. Turning first to the burden on the contractor's first amendment interests, the court concluded that the degree of coercion exerted on contractors by patronage practices was less than that on employees. While "many government workers could not find employment at the same wage in the private sector," for a contractor "there are [generally] other government entities to bid to, and private ones as well." ${ }^{\prime 86}$ Consequently, independent contractors are less dependent on the government for their livelihood than are government employees. Closely related to this argument was the court's assertion that most contractors were unlikely to feel politically independent even if afforded the protection of Elrod and Branti. Given "the pervasive role of government in modern American life" contractors would probably still feel that it was "important for [them] to be on good terms with the major political groupings in the society."

Against what the court viewed as the "uncertain benefits" to contractors' first amendment interests to be derived from extending Elrod and Branti to public contractors, the court weighed its concern for the "unknown but potentially large costs" such a rule might impose on the political system. ${ }^{68}$ While statutory re-

Bs 712 F.2d 292 (7th Cir. 1983), cert. denied, 104 S. Ct. 712 (1984).

Bs Id. at 294.

${ }^{67}$ Id. The LaFalce court did not even mention the further first amendment concern identified in Elrod: that patronage might distort the uninhibited exchange of ideas. This comment will argue, see infra notes 96-114 and accompanying text, that this concern about distortion is indeed an important one.

${ }^{68}$ LaFalce, 712 F.2d at 294. 
forms in many jurisdictions ${ }^{69}$ and the Elrod and Branti decisions themselves had gone far toward eliminating patronage from the American political scene, the court argued, patronage was still an integral part of many political institutions; the minor incremental gains in first amendment interests obtainable by extending Elrod and Branti to public contractors were too attenuated to overcome this entrenched governmental practice. ${ }^{70}$ Since the Supreme Court itself seemed to indicate a desire to limit Elrod and Branti to employee dismissals only, ${ }^{71}$ the court felt particularly reluctant to extend those cases so dramatically. ${ }^{72}$

\section{Comparing the First Amendment and Government Inter- ests in Patronage Employment and Patronage Contracting DECISIONS}

Elrod and Branti held that the patronage system sufficiently impaired the first amendment interests of public employees to require prohibiting patronage firings absent both a compelling government interest and the lack of less restrictive means of serving that interest. At first blush, the reasoning of these decisions would appear to control public contractor cases such as LaFalce. The LaFalce court sought to draw a line between public employees and public contractors on the basis of distinctions in what it perceived to be the relevant first amendment interests. This Part will examine these distinctions, as well as considering another first amendment interest ignored by the LaFalce court, in order to determine whether there is any principled basis upon which to distinguish patronage contracting from patronage employment. Finally, this Part will examine the pertinent government interests in order to ascertain whether, as applied to contractors, they are sufficiently weighty to justify imposing a burden on contractors' first amendment interests in spite of Elrod and Branti.

A. The First Amendment Interests of Independent Contractors 1. Interference with Individual Freedom of Expression and Association. The first step in analyzing whether public contractors

69 See supra note 5 .

${ }^{70}$ "[D]ecisions such as Elrod and Branti have reduced the role of patronage in politics but have not eliminated it entirely. The desirability of reducing it still further raises profound questions of political science that exceed judicial competence to answer ...." LaFalce, 712 F.2d at 294.

71 Id. at 295 (citing Elrod, 427 U.S. at 353).

72 Id. at 294-95. The court also expressed the fear that an extension of Elrod and Branti would "invite every disappointed bidder for a public contract to bring a federal suit against the government purchaser." Id. at 294. 
should fall within the scope of Elrod and Branti is to compare the burden on a contractor's freedom of expression and association caused by patronage to the burden on an employee's freedom caused by similar practices. Although the burden on the first amendment interests of the affected employees was the primary first amendment concern recognized in Elrod and Branti, neither of the Eighth Circuit opinions addressed this concern. The Seventh Circuit in LaFalce recognized that these freedoms were somewhat burdened by patronage contracting but concluded that the burden on the freedoms of public contractors from patronage is not nearly so great as the burden on the freedoms of public employees. ${ }^{73}$

The purpose of patronage contracting is to reward the incumbent's supporters and to encourage others to lend their support. In this sense, patronage contracting coerces contractors in exactly the same manner as patronage employment coerces employees: if a contractor wants to do business with a particular government unit, that contractor is induced, if not required, to support the party in power. This system may require campaign contributions from prospective contractors and even the expenditure of time and energy, just as it does from an employee. The contractor's personal beliefs, like the employee's, are compromised to the extent that he must align himself with the incumbent in order to obtain the soughtafter government benefit."

The court in LaFalce distinguished contracting from employment on the basis of the degree to which free belief and association are compromised in the two contexts, arguing that losing a contract is not like losing a job since there are other governmental and private entities to whom a contractor may bid. Therefore, the LaFalce court concluded, the public contractor is less dependent on any one political entity for its livelihood..$^{75}$ This argument rests on the doubtful premise that a minor difference in the degree of infringement of first amendment interests should alter the result. The same fundamental first amendment interest is violated by patronage contracting as by patronage employment. Where first

73 See supra note 66 and accompanying text.

I4 See Elrod, 427 U.S. at 355 ("The financial and campaign assistance that [the employee] is induced to provide to another party furthers the advancement of that party's policies to the detriment of his party's views . . . ."); supra note 14 (discussing freedom not to speak or associate).

${ }^{7 s}$ LaFalce, 712 F.2d at 294. 
amendment interests are concerned, minor variations in degree do not ordinarily suffice to alter results. ${ }^{76}$ The court in LaFalce merely asserts a difference in degree without explaining why it alters the balance struck in Elrod and Branti. One would suppose that the government interests would still have to be compelling, and the means chosen the least restrictive available, for the government to justify the infringement. ${ }^{77}$ But the court in LaFalce did not even undertake this analysis. It was content to rely on a perceived difference in the degree of coercion between contractors and employees as grounds to ignore Elrod and Branti and apply a very lax standard of review. ${ }^{78}$

Moreover, even were such matters of degree a proper basis for distinguishing between contractors and employees, the LaFalce court is simply incorrect as a factual matter. The court's finding of reduced coercion in the case of contractors ignores the reality of the environment in which many contractors compete. Available contracts are not necessarily more plentiful to a contractor than are jobs to an individual, especially for small or specialized contractors. ${ }^{79}$ Considering the marginal profitability of many contractors and the high cost of carrying equipment while it remains idle, the loss of a government contract may frequently result in economic ruin for the contractor. ${ }^{80} \mathrm{~A}$ discharged employee, on the

78 See, e.g., Wooley v. Maynard, 430 U.S. 705, 715 (1977); cf. Elrod v. Burns, 427 U.S. $347,359-60 \mathrm{n} .13$ (1976). One might argue that a sufficiently minimal infringement of a first amendment interest would not require judicial intervention. Not even the LaFalce court was willing to argue that the first amendment interests of contractors in the patronage context are minimal. The court argued only that contractors are less coerced. Moreover, the Supreme Court has never recognized such a de minimis exception for content-based first amendment infringement. Cf. Wooley v. Maynard, 430 U.S. 705 (1977) (state requirement that plaintiff's license plate bear the state motto violates first amendment); Spence v. Washington, 418 U.S. 405, 411 n.4 (1974) (rejecting claim that infringement of freedom of expression under flag use statute was " 'miniscule and trifling'").

77 The requirement that the asserted governmental interest be compelling and the infringement of first amendment interests the least restrictive available to further those government interests is the traditional test applied by the Court where the government defends a content-based infringement of first amendment interests on the basis of countervailing government interests. See infra note 116. This test was used in Elrod itself. See 427 U.S. at $362-63$.

${ }^{78}$ In LaFalce, the Seventh Circuit did not require that the interests be compelling, nor did it consider the existence of less restrictive alternatives. Instead, the court merely concluded that the government interests (which it did not recite) sufficed to justify the first amendment infringement. 712 F.2d at 294.

70 The unavailability of alternative contracts may be particularly severe during periods of recession, when the competition for available contracts is likely to be especially stiff.

so Cf. Copper Plumbing \& Heating Co. v. Campbell, 290 F.2d 368, 372 (D.C. Cir. 1961) ("We appreciate that the withholding of government business for three years may be a very serious blow to an enterprise specializing in such business."). 
other hand, can at least count on unemployment benefits and accumulated savings to get him or her through the transition to a new job in the private sector. In addition, a contractor may be no more free to move to a new location to seek work than an employee, a factor that takes on crucial importance where, for example, the government entity covers a wide geographical area or is the major source of contracted work, or where the nature of the work done by the contractor is so specialized that it can only be done for government entities. ${ }^{81}$ One is simply unable to conclude that public contractors are, as a group, less dependent on government work for their livelihood than are public employees. ${ }^{82}$

The flaw in the LaFalce analysis is apparent even without investigating the relative vulnerability of public contractors and employees to the loss of government largess. The LaFalce court assumed that no first amendment interest is infringed unless the victim is coerced into supporting a party he would not support oth-

81 See M. Johnston, supra note 4, at 21; Reich, The New Property, 73 YALE L.J. 733, 755 (1964). Road construction is a good example of work done primarily by governments.

${ }^{82}$ A second reason was advanced by the court in LaFalce to support its conclusion that the first amendment rights of public contractors are less interfered with by patronage. Many firms try to remain on good terms with both parties due to the "pervasive role of government in modern American life." 712 F.2d at 294. Characterizing these firms as "political hermaphrodites," the court explained that they tend to support all parties in an exercise of "cautious neutrality." Id. Though meant to explain why an extension of Elrod and Branti to contractors would have no real impact on contractors' behavior, the argument supports precisely the contrary conclusion. Contractors are businessmen, and to the extent that they are induced by the hope of obtaining contracts, they will only support those candidates or parties most likely to be capable of giving them those contracts. As a result, even if the court's reasoning is meant to imply that most contractors simply do not care if they have a constitutional right to be free from political coercion, the practice results in a distortion of the marketplace of ideas in favor of incumbents. See infra notes 96-114 and accompanying text (explaining why such a content-based distortion violates the first amendment). Furthermore, even if the court's characterization of contractors as "political hermaphrodites" is correct, it explains precisely why contractors should be afforded first amendment protection from patronage practices: by succumbing to the demands of the environment in which they operate, an entire segment of society has been politically neutralized. $C f$. First Nat'l Bank v. Bellotti, 435 U.S. 765 (1978) (Massachusetts law prohibiting certain corporations from spending money on public referenda impermissibly stifed free and open discussion of vital governmental affairs). The likelihood that most contractors would remain politically neutral despite a court's holding patronage contracting unconstitutional is hardly a reason to deprive those contractors who want to exercise their first amendment rights of the ability to do so without risking economic ruin. One might just as well argue that loyalty oaths or oaths proclaiming the existence of God may be required as a condition for public office because most people who take them do not really believe in them anyway. See Keyishian v. Board of Regents, 385 U.S. 589 (1967) (law requiring loyalty oath from teachers held unconstitutional); Torcaso v. Watkins, 367 U.S. 488 (1961) (law requiring public officials to affirm belief in God held unconstitutional). 
erwise. ${ }^{83}$ Of course, if the contractor or employee agrees to forego the expression of his true beliefs in order to obtain the government benefit, he has indeed successfully been coerced by the system. The court in LaFalce distinguished between contractors and employees because it felt that the economic independence of contractors made them less vulnerable to what it admitted was coercion and more able to refuse to accede to such conditions. If, however, a contractor or employee values his personal beliefs more than he does the governmental benefit, and accordingly foregoes the rewards offered by patronage, then he has still been penalized for his beliefs to the extent of the benefit foregone. Thus, the dismissed assistant public defenders in Branti were not coerced into changing their party affiliations: they were simply fired and given no choice at all. ${ }^{84}$ The LaFalce analysis is wrong because there is no meaningful distinction between successfully coercing a party into foregoing his beliefs, and penalizing a party for maintaining them. ${ }^{85}$

The Supreme Court addressed the distinction between interference with the rights of government employees and interference with the rights of contractors in Lefkowitz $v$. Turley. ${ }^{86}$ In that case the Court struck down a New York statute requiring public contractors to waive their fifth amendment immunity from self-incrimination in any proceedings related to their government contracts or suffer a five-year bar from further business with public authorities. The Court rejected the state's argument that, since contractors are less dependent upon government transactions for their livelihood, the case was distinguishable from prior cases holding such requirements unconstitutional as applied to employees:

We fail to see a difference of constitutional magnitude between the threat of job loss to an employee of the State, and a threat of loss of contracts to a contractor. . . . .

ss See LaFalce, 712 F.2d at 294.

see supra note 45.

${ }^{8 s}$ [T] $T$ he inducement afforded by placing conditions on a benefit need not be particularly great in order to find that rights have been violated. Rights are infringed both where the government fines a person a penny for being a Republican and where it withholds the grant of a penny for the same reason.

Elrod, 427 U.S. at 359-60 n.13; see Schoen, Politics, Patronage, and the Constitution, 3 IND. Lrgal F. 35, 59 (1969); cf. Dunn v. Blumstein, 405 U.S. 330, 339-40 (1972) (immaterial whether state durational residency requirements for voting actually deterred individuals from exercising the right to travel; because they penalized the exercise of that right, the requirements were unconstitutional conditions).

s6 414 U.S. 70 (1973). 
... A significant infringement of constitutional rights cannot be justified by the speculative ability of those affected to cover the damage. ${ }^{87}$

While the holding in Lefkowitz does not control the constitutionality of patronage contracting, since very different constitutional interests are at stake, ${ }^{88}$ its reasoning does support the conclusion that contractors cannot be considered any less coerced by the threat of the loss of a government benefit than can employees.

Beyond the effect of patronage contracting on the public contractor itself, one must also consider the effect of that practice on the contractor's employees. Unlike government employers, a private employer has freedom to hire and fire employees for almost any reason. ${ }^{89}$ Pressure placed on the public contractor-employer to support the incumbent political party may lead to similar pressure by the contractor upon his employees. ${ }^{80}$ To the extent that the employees are thereby forced to contribute time and money to a party against their will, the government is merely doing indirectly what it is forbidden to do directly under Elrod and Branti. This is not to say that the public contractor is constitutionally prohibited from hiring and firing its employees on the basis of political affiliation; rather, it is to assert that, to the extent that it encourages

87 Id. at 83-84 (footnote omitted).

${ }_{83}$ The fifth amendment privilege against self-incrimination is nearly absolute, see Lefkowitz, 414 U.S. at 78 ("[C]laims of overriding interests are not unusual in Fifth Amendment litigation and they have not fared well."), while first amendment intrusions may be justified by compelling governmental interests. In fact, the court in Fox \& Co. rejected an argument based upon Lefkowitz, 671 F.2d at 305 n.3, although its sole reason for doing so was its observation that Chief Justice Burger and Justices Stewart, Powell, and Rehnquist, all of whom joined the majority opinion in Lefkowitz, had each dissented in at least one of the patronage employment decisions. Based on this observation, the court concluded that " $a$ different analysis may apply in weighing governmental interests against first amendment rights, ... and against fifth amendment rights . . . II. Nonetheless, at the very least Lefkowitz provides strong support for finding the distinction between employees and contractors irrelevant. See also supra note 7 (distinction generally ignored for constitutional purposes).

${ }_{89}$ There are, of course, important exceptions to this statement, such as the limits imposed by Title VII of the Civil Rights Act of 1964, tit. VII, §§ 703(a), 704, 42 U.S.C. §§ $2000 \mathrm{e}-2(\mathrm{a}), 2000 \mathrm{e}-3$ (1982), or restrictions contained in a collective bargaining agreement with a union. Since, however, limitations such as those found in the first amendment or in the equal protection clause apply only to government, a private employer is free to impose conditions on employment that would violate these provisions if imposed by a government entity.

${ }^{90}$ See Reich, supra note 81, at 751. Professor Reich points out that the government contractor's uncertainty about his rights magnifies the impact of conditions imposed by government concerning whom the contractor may employ: "[A] government contractor may be so anxious to root out 'disloyal' employees that he dismisses men who could probably be retained consistently with government policy." $I d$. 
contractors to do so, ${ }^{91}$ the practice of patronage contracting by government constitutes an impermissible governmental interference with the employees' first amendment rights. ${ }^{92}$

The likelihood that government will use this indirect pressure on contractors' employees in an effort to coerce support is actually enhanced after Elrod and Branti. By removing government's ability to coerce such support through patronage employment practices, those decisions are likely to encourage an increased emphasis on patronage contracting as one of the last great strongholds of the patronage system. ${ }^{.3}$ As a result, many elected officials will be inclined to contract out an increasing percentage of the government services now performed by public employees in an effort to increase their power base. The public employees whose services are no longer needed could then be freely discharged on the grounds that their jobs are no longer necessary, ${ }^{94}$ and the government could then freely pressure contractors and their employees to support the incumbent political party. Under these circumstances, the victory won by public employees in Elrod and Branti would be a hollow one indeed..$^{95}$

21 Of course, encouragement from the contractor-employer may not be needed for employees to feel the pressure of patronage contracting. A union local, for example, may endorse a challenger for public office only at the risk of losing a large contract for its employer, and thus work for its members, later on. Such a result can be viewed as a penalty on the union's exercise of its first amendment rights.

${ }^{22}$ Cf. Abood v. Detroit Bd. of Educ., 431 U.S. 209 (1977) (nonunion teachers could not be forced by the state to contribute fees to the teachers union where such fees were used for political purposes contrary to the teachers' beliefs); United States v. Robel, 389 U.S. 258 (1967) (invalidating a law forbidding Communist Party members to work for private defense contractors as violative of the employee's first amendment freedom of association).

os See Note, Elrod v. Burns: Chipping at the Iceberg of Political Patronage, 34 Wash. \& LeE L. Rev. 225, 242-43 (1977); 18 B.C. Indus. \& Com. L. Rev. 782, 802-03 (1977). The recent struggle over control of city contract awards between Mayor Washington and City Council President Vrdolyak in the City of Chicago provides an instructive illustration. Deprived of the power base formerly provided by Chicago's extensive patronage employment system, both factions found contract awards to be a vital source of power in their efforts to control city government. See N.Y. Times, Aug. 19, 1983, at D16, col. 1; id., May 28, 1983, at 46 , col. 3.

94 See State ex rel. Sigall v. Aetna Cleaning Contractors, 47 Ohio App. 2d 242, 248, 353 N.E.2d 913, 916-17 (1974) (state decision to contract out services previously performed by civil service employees approved since substantial savings resulted), aff'd, 45 Ohio St. 2d 308, 345 N.E.2d 61 (1976) (per curiam). But see Washington Fed'n of State Employees v. Spokane Community College, 90 Wash. 2d 698, 702-03, 585 P.2d 474, 477-78 (1978) (en banc) (state may not contract out services ordinarily provided and capable of being provided by civil service employees despite cost savings, because policies behind civil service laws, such as avoidance of spoils system, would be defeated).

${ }_{05}$ There are, of course, practical limitations on the extent to which government jobs can be contracted out, but the possibility adumbrated in the text illuminates the frailty of the distinction between employees and independent contractors where first amendment 
2. Interference With Uninhibited, Robust, and Wide-Open Public Debate. The discussion has thus far addressed only the first amendment interest acknowledged by the LaFalce court-the right of an individual to hold beliefs and associate with others for the advancement of those beliefs without interference from government. Yet the Elrod plurality relied on ${ }^{96}$ and the Branti majority acknowledged, ${ }^{97}$ a second important first amendment interest at stake in patronage practices-a concern that government action not distort the public debate. ${ }^{98}$ By focusing only on the effect patronage has on individual contractors, the LaFalce court failed to consider the effect of patronage contracting on the nature and volume of political discourse that patronage contracting stimulates.

One of the principal functions of the first amendment is to guarantee the free expression of competing ideas concerning governmental affairs. ${ }^{99}$ This guarantee requires the complete absence of government interference so that different views may compete freely for adherents in a marketplace of ideas. ${ }^{100}$ Government actions that affect the content of the ideas available in this open marketplace tend seriously to undermine two of the principle purposes of free speech: they distort the search for truth, ${ }^{101}$ and they distort the process, so essential to the effective operation of a selfgoverning society, by which the citizen makes decisions on matters of public policy for himself. ${ }^{102}$ The first amendment concern with the quality of public discussion is distinct from the concern for in-

rights and patronage are concerned. See supra notes 79-88 and accompanying text; cf. White v. Massachusetts Council of Constr. Employers, Inc., 103 S. Ct 1042, 1046 n.7 (1983) (upholding a Boston executive order requiring $50 \%$ of all workers on city construction contracts to be residents of the city, and noting that "[e]veryone affected by the order is, in a substantial if informal sense, 'working for the city" ").

${ }^{96}$ See Elrod, 427 U.S. at 356-58; supra notes 16-19 and accompanying text.

${ }^{97}$ See Branti, 445 U.S. at 514 n.8; supra note 53.

${ }^{23}$ See A. Meiklejohn, Political Freedom 27 (1960); Stone, supra note 20, at 194-200; Stone, Restrictions of Speech Because of its Content: The Peculiar Case of Subject-Matter Restrictions, 46 U. CHI. L. Rev. 81, 101-04 (1978). Professor Stone explains that a law with content-based effects violates the first amendment "not because such a law restricts 'a lot' of speech, but because by effectively excising a specific message from public debate, it mutilates 'the thinking process of the community,' and is thus incompatible with the central precepts of the first amendment." Stone, supra note 20, at 198 (footnote omitted).

${ }^{99}$ See Mills v. Alabama, 384 U.S. 214, 218 (1966).

${ }^{100}$ See Buckley v. Valeo, 424 U.S. 1 (1976) (per curiam) (government may not seek to enhance the voices of some in order to equalize their ability to compete in the marketplace of ideas).

101 See Gertz v. Robert Welch, Inc., 418 U.S. 323, 339-40 (1974); Abrams v. United States, 250 U.S. 616, 630 (1919) (Holmes, J., dissenting); Stone, supra note 98, at 101; see also J.S. MiLL, ON LIBERTY passim (London 1859).

${ }^{102}$ See A. MeIkLejohn, supra note 98, passim; Stone, supra note 98, at 101. 
dividual self-expression, though the two are often interrelated: "[S]peech concerning public affairs is more than self-expression; it is the essence of self-government."

What political parties seek most from a system of awarding public contracts on the basis of political support is financial contributions, ${ }^{104}$ which they can then use to make their appeal to the voters. There is nothing wrong with government practices that seek to stimulate public discussion by facilitating political campaigns, but when government undertakes to stimulate public discussion, it may not do so in a way that benefits one competing set of ideas to the detriment of another. Government is required to observe a strict neutrality with respect to the content of public debate, and a government practice that favors a particular idea, viewpoint, or item of information violates the first amendment except, perhaps, in the most extraordinary of circumstances. ${ }^{105}$ In First National Bank v. Bellotti, ${ }^{106}$ for example, the Court invalidated a state law that prohibited corporations from spending money to influence public opinion on ballot referenda except with respect to a narrowly limited category of referenda questions. Without reservation, the Court declared that "where, as here, the legislature's suppression of speech suggests an attempt to give one side of a debatable public question an advantage in expressing its views to the people, the First Amendment is plainly offended."107

Bellotti is an example of government altering the relative content of the public discussion by suppressing certain viewpoints. Patronage contracting, on the other hand, works by supporting one viewpoint. The distinction is irrelevant: in either case, the ef-

${ }^{10 s}$ Garrison v. Louisiana, 379 U.S. 64, 74-75 (1964); see First Nat'l Bank v. Bellotti, 435 U.S. 765,777 n.12 (1978).

104 See M. Johnston, supra note 4, at 33-34, where Johnston notes that money is the most useful of political resources because it can be used to purchase all the other political resources, stockpiled for use at the most advantageous moment, and "given with the name of the donor clearly understood, so that a politician or bureaucrat knows clearly to whom he or she is indebted." Id. at 33 (emphasis in original); see also Buckley v. Valeo, 424 U.S. 1, 19 (1976) (per curiam) ("A restriction on the amount of money a person or group can spend ... necessarily reduces the quantity of expression ... because virtually every means of communicating ideas in today's mass society requires the expenditure of money."). Patronage employment provides a party with a large number of individuals to do the leg-work needed for a successful campaign; the employees generally are not seen as a source of funds. A system of patronage contracting, on the other hand, is much more useful for providing money than for directly providing individual political workers. See M. Royko, supra note 5, at 69 ("Contractors may be the biggest of all contributors.").

${ }^{108}$ See Stone, supra note 98, passim.

106435 U.S. 765 (1978).

${ }^{107}$ Id. at 785-86 (footnote omitted). 
fect of the government action on the content of the public debate is not neutral. ${ }^{108}$ When government makes facilities available for public expression, for example, it increases the total amount of speech that will occur. But forbidding certain groups an opportunity to use those facilities to advance their ideas would be unconstitutional, and the argument that government is merely encouraging public expression of certain ideas without suppressing any others is not a sufficient answer. ${ }^{109}$ Such a practice is unconstitutional because its effect-to make one idea more prominent and more widely disseminated, relative to its competitors, than it would be without government intervention-is as lacking in neutrality as direct suppression of disfavored ideas. As the Court stated in Police Department v. Mosley:

[G]overnment may not grant the use of a forum to people whose views it finds acceptable, but deny use to those wishing to express less favored ... views. . . . There is an "equality of status in the field of ideas," and government must afford all points of view an equal opportunity to be heard. Once a forum is opened up to assembly or speaking by some groups, government may not prohibit others from assembling or speaking on the basis of what they intend to say. Selective exclusions from a public forum may not be based on content alone, and may not be justified by reference to content alone. ${ }^{110}$

Patronage contracting results in precisely such content-based discrimination. ${ }^{111}$ It is probably true that patronage contracting leads to a greater aggregate level of contributions to political parties by encouraging a number of otherwise politically neutral con-

${ }^{108}$ Cf. Abood v. Detroit Bd. of Educ., 431 U.S. 209, 234 (1977) ("The fact that the appellants are compelled to make, rather than prohibited from making, contributions for political purposes works no less an infringement of their constitutional rights." (footnote omitted)).

${ }^{109}$ See, e.g., Widmar v. Vincent, 454 U.S. 828 (1981); Carey v. Brown, 447 U.S. 455 (1980); Police Dep't v. Mosely, 408 U.S. 92 (1972). See generally Stone, supra note 98, at 201-07 (discussing the role of equality in first amendment jurisprudence).

110408 U.S. 92, 96 (1972) (footnote omitted) (quoting A. MEIKLEJOHN, supra note 98, at 27).

11 Indeed, one might argue that the harm is even greater in the patronage contracting context than in the public forum context. A group denied access to one forum may still be able to convey its message by shifting, at little or no additional expense, to another forum. A group that is disadvantaged by the advancement of funds to a competing group through a practice such as patronage contracting has no similar opportunity. It must make additional expenditures to recover the loss. In any event, the Court has rejected the argument that the availability of alternative means of expression may justify a content-based regulation of speech. See L. Tribe, American Constitutional Law § 12-8, at 603-04 (1978) (citing cases). 
tractors to contribute in order to reap the benefits of government contracts. These contributions, however, are seldom if ever evenly divided among all parties or candidates. Incumbents or heavily favored candidates benefit disproportionately, since they offer the contractor the greatest likelihood of success in realizing the benefit. ${ }^{112}$ Thus, patronage contracting, as an informal method of financing political campaigns, operates in a manner that discriminates on the basis of the ideas being advanced. ${ }^{113}$ Indeed, as this analysis has demonstrated, patronage contracting is, practically speaking, no different than a hypothetical campaign-finance law that only provides money to incumbents. ${ }^{114}$

112 During the Johnson Administration, a number of architectural and engineering firms that had made substantial contributions to the President's Club received lucrative government contracts. Many of these contributors were prominent Republicans. M. ToLchiN \& S. TolchiN, supra note 4, at 275-77. "[T] he Republicans resented the opportunities for patronage which cut so deeply into the structure of the Republican Party. What motivations existed for maintaining party loyalty, they asked, in the face of such overwhelming patronage bait dangled so flagrantly from the executive branch of government?" Id. at 276. When Hubert Humphrey later tried to resurrect Johnson's President's Club to solicit contributions for his 1968 campaign, he met with little success: "Perhaps, . . . with Humphrey already acknowledged by many analysts as the losing candidate, politically acute contributors saw little chance of promises of potential patronage being actualized." Id. at 276; see also M. RoYKo, supra note 5, at 69 ("Even Republican businessmen contribute money to the [Democratic] Machine, more than they give to Republican candidates. Republicans can't do anything for them, but Daley can.").

113 Patronage is a peculiar type of content-based discrimination; since both parties can use it, it appears to be viewpoint neutral. Yet patronage is content based in the sense that it favors incumbents whether they be Democrats, Republicans, or Socialists. The Court has wavered in its treatment of viewpoint-neutral restrictions, sometimes treating them as content based and other times as content neutral. See Stone, supra note 98 , at $83-100$. However, there is no doubt that patronage practices are and should be treated as content-based restrictions and so subjected to strict scrutiny. The viewpoint neutrality of patronage is deceptive. With any given administration, the practice is clearly not viewpoint neutral, but favors the party in power. An appearance of neutrality derives solely from the possibility that a subsequent administration may be of another view. One might as well argue that a law that said "All Democrats shall be fined $\$ 100$ " was viewpoint neutral because a later administration might fine Republicans instead. See Elrod, 427 U.S. at 360 ("[R]egardless of how evenhandedly these restraints may operate in the long run, after political office has changed hands several times, protected interests are still infringed and thus the violation remains.").

116 [T] the way government funds are expended [to support free expression.] In general these limitations would be the same as in the case of the government furnishing physical facilities: there could be no discrimination between users and no regulation of content. T. Emgrson, The System of FreEdom of Expression 651 (1970) (footnote omitted); see also Branti, 445 U.S at $517 \mathrm{n.12}$ ("Government funds, which are collected from taxpayers of all parties on a nonpolitical basis, cannot be expended for the benefit of one political party simply because that party has control of the government."). 


\section{B. The Government Interests}

Having established that patronage contracting infringes important first amendment interests, this comment now turns to the question whether there exist government interests in the patronage contracting context that, unlike the interests asserted in support of patronage employment in Elrod, ${ }^{115}$ justify the impairment of first amendment rights. Because the challenged practice infringes a first amendment interest, the state interests advanced to justify it are measured against a strict standard. To survive constitutional challenge, patronage contracting must "further some vital government end by a means that is least restrictive of freedom of belief and association in achieving that end, and the benefit gained must outweigh the loss of constitutionally protected rights."116

${ }^{115}$ See Elrod, 427 U.S. at 364-73; supra notes 20-27 and accompanying text.

${ }^{116}$ Elrod, 427 U.S. at 363 (footnote omitted); see Branti, 445 U.S. at 515-16. This standard is uniformly invoked when speech is regulated on the basis of its viewpoint, regardless of whether the first amendment interest at stake is that of the individual or is a concern with the quality of debate. Compare Kusper v. Pontikes, 414 U.S. 51, 58-59 (1973) (strict scrutiny for interference with personal freedom of belief or association), and United States v. Robel, 389 U.S. 258, 268 n.20 (1967) (same), with First Nat'l Bank v. Bellotti, 435 U.S. 765, 786 (1978) (strict scrutiny for discriminatory interference with free and open discussion), and Police Dept. v. Mosley, 408 U.S. 92, 98-99 (1972) (same). See L. TrIBE, supra note $111, \S 12-8$, at $602-04$. In applying this standard, the Elrod plurality stressed that "[i]t is firmly established that a significant impairment of First Amendment rights must survive exacting scrutiny," and that "the burden is on the government to show the existence of [a paramount] interest." 427 U.S. at 362 (citations omitted). This strict standard of scrutiny has been applied by the lower courts in other employee-discharge cases, see, e.g., Wren v. Jones, 635 F.2d 1277, 1282 (7th Cir. 1980), cert. denied, 454 U.S. 832 (1981), but was not applied by the Seventh and Eighth Circuits in the patronage contracting decisions. The Eighth Circuit, content to rely exclusively on the distinction between contractors and employees, declined, in Sweeney v. Bond, 669 F.2d 542 (8th Cir. 1982), and Fox \& Co. v. Schoemehl, 671 F.2d 303 (8th Cir. 1982), to engage in any constitutional balancing at all. See supra notes 58-64 and accompanying text. The Seventh Circuit, in LaFalce v. Houston, 712 F.2d 292 (7th Cir. 1983), applied, without explanation, an ad hoc balancing of interests, id. at 294-95, rather than requiring a "compelling" government interest, as the plaintiff had urged, Brief for Appellant at 16, LaFalce v. Houston, 712 F.2d 292 (7th Cir. 1983).

One might argue that a lower standard should apply because most contractors are corporations rather than individuals. In First Nat'l Bank v. Bellotti, 435 U.S. 765 (1978), the state argued, in support of a law restricting corporate campaign expenditures, that since corporations are not natural persons, the first amendment, which the state contended is closely identified with the notion of personhood, simply does not apply. Id. at 778 \& n.14. The Court unequivocally rejected the contention: "We thus find no support in the First or Fourteenth Amendment, or in the decisions of this Court, for the proposition that speech that would be within the protection of the First Amendment loses that protection simply because its source is a corporation ... " Id. at 784; see also id. at 778-79 n.14. But cf. Stone, supra note 20, at 245-51 (discussing when discrimination based on the speaker's identity is appropriate). Moreover, not all contractors are corporations. In fact, Sweeney involved individuals, Fox \& Co. involved a partnership, and LaFalce involved a sole proprietorship. Finally, even were corporations subject to less protection, patronage contracting 
While a number of justifications might be advanced in favor of patronage contracting, three stand out as the most important: the long history of the practice in American politics; the supposed contribution patronage makes to the stability of political parties; and the possible speech-inhibiting effects and effects on government decisionmaking associated with enforcing the rights of contractors should Elrod and Branti be applied to them. ${ }^{117}$

1. The History of Patronage. In his Elrod dissent, Justice Powell emphasized the role patronage has played in the history of American politics. ${ }^{118}$ The Supreme Court has occasionally sustained practices otherwise seemingly suspect under the first amendment where there has been a long history of allowing the practice. ${ }^{119} \mathrm{~A}$ court is therefore likely to exercise caution before declaring an institution thought to be constitutional for nearly 200 years unlawful. ${ }^{120}$ Whatever persuasiveness it may carry in other

would still have the effect of coercing the corporate-contractors' shareholders, managers and employees. See supra notes 89-95 and accompanying text.

117 Two other justifications put forward in support of patronage employment simply do not apply or are much weaker in the context of patronage contracting. First, the argument that patronage increases the accountability of political parties to the electorate through closer identification of the party in power with the government, see supra notes 23,35 and accompanying text, has little force in this context since the public is much less likely to identify a public contractor's work with the party in power than it is the services performed by the government itself. Second, the argument that patronage is justified by the need for loyal employees, see supra note 23, does not apply to patronage contracting at all. Public contractors are generally even further removed from the making or implementation of policy than are most public employees. Rarely privy to government inside information, contractors are in no position to "thwart the goals" of the administration, Elrod, 427 U.S. at 367. Furthermore, the contractor already has a sufficient incentive to do his job well in that a business has greater need to protect its commercial reputation than does the average employee. Finally, if the work is not done according to the terms of the contract, the government can find a remedy by refusing to pay the contractor, suing for breach of contract, or refusing to deal further with the contractor. See Copper Plumbing \& Heating Co. v. Campbell, 290 F.2d 368 (D.C. Cir. 1961) (federal government could refuse to deal with contractor for three years based on breach of contract in failing to comply with federal wage and hour requirements). If, as may occur in rare cases, the contractor performs a function for which political affiliation is an appropriate requirement (such as a firm engaged for consulting purposes in formulating policy), the Branti exception will apply. Cf. Sweeney v. Bond, 669 F.2d 542, 546 (8th Cir. 1982) (alternate holding) (even if Elrod and Branti were applicable to contractors, political affiliation is an appropriate requirement for plaintiff's position).

118 427 U.S. at 377-80. Justice Powell noted the existence of patronage practices during Washington's presidency, and dated its prevalence from the administration of Andrew Jackson. See supra note 5.

119 See, e.g., Marsh v. Chambers, 103 S. Ct. 3330 (1983) (upholding recitation by chaplain of daily prayer in opening proceedings in state legislature); $c f$. Roth v. United States, 354 U.S. 476 (1957) (holding that obscenity is not protected expression under the first amendment).

120 The plurality in Elrod did not really give this justification serious consideration, and indeed viewed the tainted history of the practice negatively, $i d$. at $353-55$, though it did not 
contexts, however, history will not support the constitutionality of patronage contracting because changing constitutional doctrine has undercut the long-standing theoretical premise-the right/privilege distinction-upon which it rested. ${ }^{121}$

Until relatively recently, courts uniformly held that since government could, if it so chose, withhold benefits altogether, it could attach any strings it chose to those benefits it decided to distribute. ${ }^{122}$ This doctrine rested on the question-begging idea that government benefits are merely privileges to which their recipients have no entitlement. In recent years the doctrine has been soundly rejected. ${ }^{123}$ The Court has replaced it with the doctrine of unconstitutional conditions, ${ }^{124}$ which holds that government may not, by attaching conditions to its largess, do indirectly that which it could not do directly: discourage private citizens from exercising their constitutional rights. ${ }^{125}$ By eliminating the doctrinal presupposi-

place history on the constitutional scales against the practice.

121 The fact that the history of patronage was unimportant to the Court in Elrod and Branti, although persuasive, does not conclude the inquiry. First, none of the opinions supporting the decisions in Elrod and Branti focused attention on the historical evidence. See supra note 120. Second, subsequent cases have relied on history as grounds for upholding entrenched practices against first amendment attack. E.g., Marsh v. Chambers, $103 \mathrm{~S}$. Ct. 3330 (1983). Finally, after Elrod and Branti, patronage contracting is one of the most important remaining tools for patronage, see LaFalce $v$. Houston, 712 F.2d 292, 294 (7th Cir. 1983), and so this long tradition of patronage takes on heightened significance in the contracting context.

${ }^{122}$ In light of this doctrine, it is easy to see why constitutional limitations on government employment practices were nonexistent for so long: government employment was not a right. See, e.g., Bailey v. Richardson, 182 F.2d 46, 61 (D.C. Cir. 1950) (rejecting plaintiff's first amendment claim on the ground that "[g]overnment employ . . . is not a right"), aff'd by an equally divided Court, 341 U.S. 918 (1952) (per curiam). For a pre-Elrod application of the distinction in a patronage employment case, see Alomar v. Dwyer, 447 F.2d 482 (2d Cir. 1971) (per curiam), cert. denied, 404 U.S. 1020 (1972).

${ }^{123}$ See supra note 15.

124 The doctrine of unconstitutional conditions has been applied, for example, to hold unlawful the dismissal of a teacher for exercising his freedom of speech, Perry v. Sindermann, 408 U.S. 593, 596-98 (1972), and the denial of unemployment benefits to a worker who could find no employment because of her religious beliefs, Sherbert v. Verner, 374 U.S. 398 (1963). For a discussion of the doctrine of unconstitutional conditions, see Van Alstyne, The Demise of the Right-Privilege Distinction in Constitutional Law, 81 Harv. L. REv. 1439, 1445-49 (1968). The doctrine was central to the plurality's decision in Elrod, see 427 U.S. at 356-60 (discussing unconstitutional conditions), 360-61 (rejecting the right/privilege distinction), and to the majority's in Branti, see 445 U.S. at 514-15.

${ }_{125}$ Van Alstyne, supra note 124, at 1445-47. Of course, the doctrine is neither to be mechanically applied nor absolute. Properly applied, the doctrine requires that the courts take account of the special nature of the relationship between an individual and the government in assessing the validity of the condition. Id. at 1448. In Civil Serv. Comm'n v. National Ass'n of Letter Carriers, 413 U.S. 548 (1973), for example, the Court upheld the constitutionality of a provision in the Hatch Act, 5 U.S.C. $\$ 7324(a)(2)$ (1982), which bars federal employees from taking an active part in partisan political activities. Although such a 
tion that for so long made the inquiry into the constitutionality of conditions on government benefits irrelevant, this change makes reliance on history and longstanding assumptions of constitutionality unpersuasive. Under the current doctrine of unconstitutional conditions, if patronage contracting, by requiring political support as a condition for obtaining a contract imposes an unconstitutional condition on the exercise of first amendment freedom, patronage contracting may itself be unconstitutional.

Moreover, circumstances have changed dramatically since patronage first emerged in this country. Government has grown tremendously at all levels; while the demand made by government on labor and services from the private sector was at one time relatively minor, government is now a major consumer of both. ${ }^{126}$ Thus, the effect of government employment and contracting practices today is of an entirely different order of magnitude from the effect of such practices 150 years ago. This dramatic shift in the relative significance of government as an employer and purchaser of goods and services calls for a reexamination of the problems associated with patronage as a matter of first principle, and makes reliance on the history of patronage contracting unsound. ${ }^{127}$

2. Contribution to Stable Political Parties. In his dissenting opinions in Elrod and Branti, Justice Powell also argued that patronage, by encouraging more people to participate in the electoral process, leads to stronger, more stable political parties. ${ }^{128}$ Without

ban would clearly have been an unconstitutional suppression of speech and association as applied to private citizens, the Court nevertheless felt that the government interest in "the impartial execution of the laws" justified this infringement. Id. at 565. The Court emphasized the fact that the ban was content-neutral and did not seek "to control political opinions or beliefs, or to interfere with or influence anyone's vote at the polls." Id. at 564. As both the Elrod plurality, see 427 U.S. at 356-61, and the Branti majority, see 445 U.S. at 514-15, recognized, however, the doctrine is properly applied in the patronage context.

${ }_{136}$ In 1976, federal, state, and local governments were estimated to be directly employing $18.4 \%$ of the workforce and indirectly employing an additional $11.2 \%$ through purchases of goods and services from the private sector. L. Thurow, The Zero-Sum Society: Distribution and the Possibilities for Economic Change 162, 165 (1980).

127 As Justice (then Judge) Stevens pointed out in the first court of appeals decision to hold patronage dismissals unconstitutional, "if the age of a pernicious practice were a sufficient reason for its continued acceptance, the constitutional attack on racial discrimination would, of course, have been doomed to failure." Illinois State Employees Union v. Lewis, 473 F.2d 561, 568 n.14 (7th Cir. 1972), cert. denied, 410 U.S. 928, and cert. denied, 410 U.S. 943 (1973), quoted in Elrod, 427 U.S. at 369 n.22. Charles Reich argues that the tremendous growth of government largess has given the government so much economic leverage that, if left unchecked, the government could effectively buy the constitutional rights of many of its citizens. Reich, supra note 81 , at 779 .

${ }^{128}$ Branti, 445 U.S. at 527-32 (Powell, J., dissenting); Elrod, 427 U.S. at 383-85 (Powell, J., dissenting). 
the prospect of material reward, he contended, few people would willingly involve themselves in local elections, since these elections ordinarily stimulate little public interest. This result, Justice Powell concluded, would seriously harm the democratic process. While this argument did not prevail in Elrod or Branti, ${ }^{129}$ it takes on added significance after those decisions in the context of patronage contracting as one of the most important remaining forms of patronage. Even if one concedes that some system for financing political parties is necessary to insure their stability, however, this necessity cannot sustain the practice of patronage contracting because that practice infringes on first amendment interests through a means that is not the "least restrictive of freedom of belief and association."130

The contribution that patronage employment makes to political parties comes primarily in the form of active campaign participation. A political party, especially at the local level, needs committed members to get out the vote for the party's candidate. The material rewards offered by the prospect of a patronage job arguably serve this purpose well. ${ }^{131}$ Nonetheless, Elrod and Branti held this laudable result of patronage employment insufficient to justify the first amendment infringements by which it is achieved. And if it is insufficient to justify patronage employment, this rationale cannot possibly serve to justify patronage contracting, to which it applies much less strongly. The contribution expected of contractors generally comes in the form of financial assistance. ${ }^{132}$ Such contributions, however, do not directly serve the purpose of stimu-

129 The plurality in Elrod and the majority in Branti answered this contention by pointing out that patronage is not essential to partisan politics, as is shown by the survival of political parties even where merit civil service systems have replaced patronage employment. In addition, patronage, as an infringement of first amendment interests, can only be justified by a true government interest, not a purely partisan one. Branti, 445 U.S. at 517 n.12; Elrod, 427 U.S. at 362 . Even if that partisan interest strengthens the democratic process by greater participation, the opinions argued, it also weakens it by skewing the balance of participation in favor of the incumbent party. Elrod, 427 U.S. at 368-70; see supra note 27.

1so See Elrod, 427 U.S. at 363; supra note 116.

131 Of course, there are a few who share the view, characterized by Justice Powell as "naive," Elrod, 427 U.S. at 385, that other factors, such as civic or intellectual interest, stimulate participation in partisan politics as well as the prospect of material reward. See, e.g., F. Soraur, supra note 4, at 82-90.

${ }^{132}$ See supra note 104. Patronage contracting may also lead to contributions from the contractor and its employees in the form of time and effort spent campaigning for the incumbent, but such contributions are clearly secondary, and, to the extent they are induced by the prospect of contract awards, they can be no more justified than in the case of patronage employment. See supra notes $89-95$ and accompanying text. 
lating interest in elections; they merely provide the party that receives them with the resources to pay others to achieve this end. An equally effective, but less restrictive, means of financing local politics is available in the form of public campaign finance laws in which funds are disbursed equally to all parties. ${ }^{133}$ This alternative has the same stabilizing effect on political parties as the extraction of funding through patronage contracting without infringing the first amendment rights of anyone. ${ }^{134}$

Finally, there is a sense in which this entire asserted justification is paradoxical. At bottom, this justification is based on an assumption that government has an interest in assuring that people participate in the political process and that since, if left alone, people will not participate, government therefore has an interest in inducing them to do so. But the first amendment protects not only the right to speak but also the right not to speak, ${ }^{195}$ and it can hardly be argued that an asserted government interest in violating the first amendment rights of individuals not to participate in the political process can serve to justify the subordination of those rights. ${ }^{138}$

3. Enforcement Problems: Effects on Governmental Decisionmaking and on Contractors' Speech. Perhaps the strongest argument against applying Elrod and Branti to patronage contracting arises from the consequences that attempts to enforce such an extension would have on governmental decisionmaking. ${ }^{137}$ Govern-

12s See, e.g., Presidential Election Campaign Fund Act, 26 U.S.C. $\$$ 9001-13 (1982).

194 Contributions to political parties from public contractors seeking rewards are to some extent already indirectly financed from the public treasury in the form of higher contract costs.

${ }^{135}$ See supra note 14.

198 This argument demonstrates the fundamental conflict between the first amendment and a political system based on interest group politics. In Part III infra, this comment will argue that concerns about this conflict may well explain the reluctance of the courts of appeals to extend Elrod and Branti beyond their narrow holdings. See infra notes 151-67 and accompanying text.

${ }^{137}$ One additional argument in favor of patronage practices that has been advanced in none of the patronage cases to date is that government has the same degree of discretion when it acts in its proprietary capacity as does a private party. In Perkins v. Lukens Steel Co., 310 U.S. 113 (1940), the Supreme Court held that prospective government contractors lacked standing to challenge the Secretary of Labor's application of a statute that imposed minimum wage requirements on federal government contractors. The Court stressed that

[l]ike private individuals and businesses, the Government enjoys the unrestricted power to produce its own supplies, to determine those with whom it will deal, and to fix the terms and conditions upon which it will make needed purchases. . . . [The] Act ... embodies the traditional principle of leaving purchases necessary to the operation of our Government to administration by the executive branch of Government, with adequate range of discretion free from vexatious and dilatory restraints at the suits of 
mental hiring decisions involving nonpolicymaking employees are not as complex as governmental contracting decisions for two reasons. First, the going wage for a government employee is usually fixed, and therefore the employee's "price" is not a criterion for deciding whom to employ. Second, the qualifications for employment are usually clear from the nature of the job and its history. The result is that nonpolitical reasons for an adverse employment decision, such as lack of education, misconduct, or poor performance, can easily be documented to justify the decision. Similarly, the absence of such factors is easily established, so that where no sufficient nonpolitical justification exists, a cause of action under Elrod and Branti is easily made out. Consequently, government officials are put on notice as to the limits of their discretion with respect to employment decisions. ${ }^{138}$ Moreover, given the expense

prospective or potential sellers.

Id. at 127. Perkins thus apparently held that government could, in its proprietary capacity, contract on any terms it wished, subject only to ultimate political accountability. In a recent line of cases involving the dormant commerce clause, the Court has extended this principle to the states. See White v. Massachusetts Council of Constr. Employers, Inc., $103 \mathrm{~S}$. Ct. 1042 (1983); Reeves, Inc. v. Stake, 447 U.S. 429 (1980); Hughes v. Alexandria Scrap Corp., 426 U.S. 794 (1976).

In the first amendment area, the Court has also recognized that government has greater freedom to restrict speech interests in its proprietary capacity as the owner of property. See Greer v. Spock, 424 U.S. 828 (1976) (upholding ban on political activities on military bases); Lehman v. City of Shaker Heights, 418 U.S. 298 (1974) (upholding municipality's ban on political advertising in city-owned buses); Adderly v. Florida, 385 U.S. 39 (1966) (upholding conviction of demonstrators for trespassing on premises of county jail).

The unqualified version of the distinction between government action in its sovereign capacity and government action in its proprietary capacity propounded in Perkins has not survived subsequent decisions. See Wells \& Hellerstein, The Governmental-Proprietary Distinction in Constitutional Law, 66 VA. L. REv. 1073 (1980). The courts no longer mechanically apply the distinction to uphold any government action taken in an arguably proprietary capacity. Id. at 1115. Rather, the distinction survives mostly as an indicator that the government may have a separate "business-like interest" at stake for the courts to take into account in balancing interests. Id. at 1119. Thus understood, the presence of a proprietary interest, without more, will seldom suffice to support a government practice that impairs individual constitutional rights since such interests are seldom, if ever, strong enough to overcome the individual's claim to constitutional protection. See id. at 1117-20.

In addition, "[ $t$ ] he term [proprietary] does not help in cases where the constitutional challenge concerns a government that, while engaged in business dealings, cannot assert a business justification for its actions." Id. at 1119. In the patronage context, the only "business-like interests" advanced are efficiency and accountability, see supra note 23, interests that are not served by patronage contracting, see supra note 117. The principle remaining justification, the stability of political parties, is a "public interest" justification, unrelated to the contracting process itself. Thus, the fact that patronage contracting originates in a proprietary act is immaterial.

${ }_{138}$ The principal uncertainty that an official making employment decisions faces is determining whether the position is one for which political affliation is an appropriate criterion, see Branti, 445 U.S. at 523-24 (Powell, J., dissenting), not determining whether satis- 
and difficulty of proving a claim under Elrod and Branti when nonpolitical factors do form the basis of an employment decision, individuals are unlikely to bring suit unless a clear case can be made out.

The situation is both more complex and less certain from the government's viewpoint in the contracting context. When two or more prospective contractors are bidding for government contracts, price is almost always a factor. Other factors such as past performance, experience, and unique capabilities also are sure to be important, and the uniqueness of the task may make the optimal qualifications for the job uncertain and unquantifiable. Because of the preponderance of these complex unquantifiable factors in contracting decisions, it will be more difficult for a court to isolate and detect improper grounds for awarding contracts than for making employment decisions.

To give an example, suppose that two contractors are competing for a government contract for a unique government service. The first bidder has considerable experience in providing this type of service, but was also a contributor to the elected official's most recent campaign. The second bidder gave a lower bid, but has less experience in providing the service. The second bidder, however, did not contribute to the elected official's campaign. There are three possible grounds upon which the government purchaser might base his decision-price, experience, and political support. Because the job being contracted for is unique, the decisions as to which of the concededly "proper" grounds for making the decision-price or experience-should be given more weight calls for an exercise of executive judgment. ${ }^{138}$ Such judgments are extremely difficult for courts to review. For example, the official in the hypothetical case cannot be certain that a court will not later find his decision to award the job to the higher priced but more experienced bidder unconstitutional. Moreover, since the stakes in any single government contract are likely to be far higher than those involved in a single government job, the disappointed contractor is much more likely to bring a suit against the government than is the disappointed job applicant. Also, since businesses typically have more resources and greater familiarity with litigation

factory independent grounds exist for the decision.

${ }^{139}$ In a comparable employment decision, the price factor would be lacking. Thus, the only relevant, permissible, nonpolitical criterion would be experience, and an official would be perfectly free to hire a political supporter if that supporter were more experienced. 
than individuals, contractors will be better situated to bring such suits. ${ }^{140}$

The effect of this higher level of uncertainty in the contracting context is twofold. First, the fear of frivolous litigation and uncertainty over the results of judicial review of contracting decisions may lead government officials to feel themselves constrained to award all contracts on the basis of price alone, often at the cost of inadequate contract performance by inexperienced or otherwise incompetent contractors. The public interest would doubtless often be harmed by having less capable, though cheaper, contractors perform government contracts. The alternative, equally detrimental to the public interest, might well be to have every award to a contractor other than the lowest bidder litigated in a federal court. ${ }^{141}$

The second, somewhat ironic consequence of the uncertainty inherent in enforcing the rule of Elrod and Branti against patronage contracting may be to dissuade contractors from making political contributions. Either because of the in terrorem effect on government officials, or because the existence of prior political contributions could form the basis of suits by competitors to have their contract awards rescinded, contractors might legitimately fear that prior political contributions could cause them to lose contracts. ${ }^{142}$ In order to avoid such losses, many contractors might feel compelled to withhold support that they would otherwise choose to

${ }_{140}$ In LaFalce v. Houston, 712 F.2d 292 (7th Cir. 1983), cert. denied, 104 S. Ct. 712 (1984), the court was especially troubled by fears that extending Elrod and Branti to public contractors would greatly increase the amount of litigation in federal courts: "[I]t is in the nature of competitive bidding that every award of a contract involves the rejection of one or more other bids, each of which could form the basis of a federal suit under the theory advanced by the plaintiff in this case." Id. at 294.

141 One can add to this litany of adverse effects the possibility that the contract awarding process might be made more expensive. Government entities may decide that, with the added difficulties attendant upon extending Elrod and Branti to contracting, the competitive bidding process is simply too time-consuming and complicated. They may therefore choose instead to negotiate only with the single contractor they deem to be most likely to be suitable for the job. Alternatively, if contractors are accorded first amendment protection from patronage, government purchasers may feel constrained to bid out even those contracts now awarded through individual negotiations. This system at least has the advantage of reducing the number of potential litigants contesting the award to one-the lowest bidder-rather than all contractors who might claim they would have been chosen but for political considerations.

${ }_{142}$ Cf. Shakman v. Democratic Org., 435 F.2d 267 (7th Cir. 1970), cert. denied, 402 U.S. 909 (1971) (voters and candidates who allege that the city's patronage employment system denied them an equal opportunity in elections state a cause of action under the equal protection clause). In Shakman, the court warned the district court that, in fashioning a remedy on remand, "care will be required in order to distinguish between compelled and voluntary political support by public employees," since, in the absence of a statute prohibiting such conduct, "such individuals enjoy the same right of political association and expression, on their own time, as anyone else." Id. at 271. 
provide from a political party. Extending Elrod and Branti to the unique situation of contractors may thus actually result in an inadvertant suppression of speech, hardly a desirable result.

While this argument from the complexity of contracting decisions has some surface plausibility, it does not justify completely denying public contractors any protection against the infringement of their first amendment interests through the practice of patronage contracting. Though refusing to recognize a cause of action altogether alleviates these problems, such a solution is grossly overinclusive. Completely denying the existence of a right is a peculiar and overly simplistic way of avoiding problems associated with its enforcement. As with other causes of action posing similar potential drawbacks, ${ }^{148}$ these competing first amendment and government concerns can be accommodated by a careful delineation of the elements of the cause of action and a judicious allocation of burdens of proof and persuasion in light of the government official's need for certainty and discretion and the plaintiff's need for a remedy that is not so burdensome that the right becomes effectively empty.

In Mt. Healthy City School District Board of Education $v$. Doyle, ${ }^{144}$ an untenured teacher with a past history of conflict with school authorities was not rehired after he relayed information concerning school policy to a local radio station. The teacher sued, claiming that the school board's refusal to rehire him violated his first and fourteenth amendment rights. In the district court, the teacher was required, in order to prevail on the merits, to show that the protected conduct played a "substantial part" in the actual decision not to rehire him. ${ }^{145}$ The problem posed for the Court was remarkably similar to that involved in a patronage contracting case under an extension of Elrod and Branti: both involve government decisions the reasons for which may or may not be illegitimate, and both require a court to protect an individual's first amendment rights without impairing the government's ability to

14s See, e.g., Mt. Healthy City School Dist. Bd. of Educ. v. Doyle, 429 U.S. 274, 286-87 (1977) (potential difficulty in ascertaining motivation does not bar a first amendment claim, nor require that a plaintiff be in a better position than in the absence of protected conduct; instead, the burdens of production and persuasion should be structured to avoid frivolous and capture meritorious cases); Washington v. Davis, 426 U.S. 229, 253 (1976) (Stevens, J., concurring) (same with respect to showing discriminatory purpose behind facially race-neutral government action in order to show violation of the equal protection clause); Story Parchment Co. v. Paterson Paper Co., 282 U.S. 555, 563 (1931) (difficulty of ascertaining damages in a private tort suit not grounds for denying recovery altogether).

14429 U.S. 274 (1977).

148 Id. at 284. 
protect its legitimate interests. The Court's solution in Mt. Healthy, equally applicable in the patronage contracting context, adjusts the procedures under which the claim is adjudicated. The initial burden is on the plaintiff to show both that he was engaged in constitutionally protected conduct, and that this conduct was a "substantial" or "motivating" factor in the defendant's decision; the burden then shifts to the defendant to show that the same action would have been taken even in the absence of the plaintiff's protected conduct. ${ }^{148}$

In a patronage contracting case, the contractor-plaintiff would first have to show that it had not supported the incumbent official, while the contractor that received the award had done so. The contractor would also have to prove that it was fully able and qualified to perform the job, and that political considerations were a substantial factor in the decision. ${ }^{147}$ If the contractor is able to make this showing, the government defendant may still prevail by showing that it would have made the same decision even in the absence of political considerations. ${ }^{148}$

210 Id. at 287; see also Arlington Heights v. Metropolitan Hous. Dev. Corp., 429 U.S. 252, $270 \mathrm{n} .21$ (Mt. Healthy test applies in equal protection context). This approach has been uniformly applied by the lower courts in patronage employment cases under Elrod and Branti. See Gannon v. Dailey, 561 F. Supp. 1377, 1379 n.3 (N.D. Ill. 1983) (citing cases).

147 The bare allegation by a plaintiff that its bid was lower than that of the prevailing contractor would be insufficient to show that the failure to support the incumbent was a substantial factor in the decision to award the contract to someone else under the $M t$. Healthy approach because there exists the equally likely explanation that the contract was awarded to the contractor better able to perform.

${ }^{142}$ In the patronage employment cases, the courts have given considerable weight to the legitimate justifications advanced by defendants in denying relief. See, e.g., Tanner v. McCall, 625 F.2d 1183 (5th Cir. 1980) (plaintiffs denied relief where defendant showed dismissals were justified by the need for fewer and more qualified employees), cert. denied, 451 U.S. 907 (1981); Wren v. Jones, 635 F.2d 1277 (7th Cir. 1980) (fiscal restraints), cert. denied, 454 U.S. 832 (1981). In addition, the government defendant may refute the plaintiff's claim by showing that its award in the case in question was within the Branti exception in that party affiliation was an appropriate requirement for effective performance of the function. Branti, 445 U.S. at 518. Such cases in the contracting context should be rare. See supra note 117 .

In the example given previously, see supra text accompanying note 139 , the plaintiff contractor would have to prove that it did not support the incumbent, that it was fully capable of performing the contract, and that its bid was lower than that of the contractor that did support the incumbent and did receive the award. To rebut this claim, the defendant would need to show that it awarded the contract to the more experienced contractor and that it was reasonable to place more weight on experience than on price in choosing a contractor. If, however, experience was not a reasonable ground for making the award (as, for example, in the case of a contract with a wholesaler to supply paperclips), then the low bidder would prevail. The evidence taken should be limited to the information available to the official at the time of the decision so that a disappointed contractor could not later claim he was more qualified when no such information was submitted with the bid. 
Undoubtedly, the possibility of suit will create incentives for government purchasers to change the way they do business with independent contractors. ${ }^{148}$ But a carefully designed test that places a fairly heavy burden on the disappointed contractor and takes into account the government's need for reasonable discretion in awarding contracts will minimize these consequences. Whatever additional burdens are imposed upon government decisionmakers will be only those necessary in order to guard against unconstitutional government decisions. ${ }^{150}$

\section{The Patronage Contracting Decisions Revisited}

The foregoing analysis demonstrates that there is no significant difference between patronage contracting and patronage employment with regard either to the first amendment or government interests at stake. Indeed, the analysis reveals that, after Elrod and Branti, extending first amendment protection to patronage con-

The plaintiffs in Sweeney v. Bond, 669 F.2d 542 (8th Cir.), cert. denied, 103 S. Ct. 174 (1982), Fox \& Co. v. Schoemehl, 671 F.2d 303 (8th Cir. 1982), and LaFalce v. Houston, 712 F.2d 292 (7th Cir. 1983), cert. denied, 104 S. Ct. 712 (1984), would have had little difficulty making out a cause of action. The Sweeney and Fox \& Co. plaintiffs were discharged from their positions immediately upon a change in administrations and presumably were performing their functions satisfactorily. Under these circumstances, the facts fit well within the Elrod and Branti pattern of wholesale dismissals by a newly elected official so as to leave little doubt about the motivation for the acts. The LaFalce case is more difficult since a new contract bid was involved rather than the discontinuation of services previously contracted for. The contract was only for the installation of benches along city streets, however, and few factors other than price would ordinarily enter into such a contracting decision in the absence of political considerations. Thus, a claim under Elrod and Branti, as applied to contractors, seems fairly clear-cut.

140 See supra notes $140-41$ and accompanying text. In many cases, government may bid out contracts that might previously have been negotiated with only one contractor. Criteria for awarding contracts may have to be designated in advance in order to protect against being second-guessed by a court in a lawsuit. These by-products of extending the protection of Elrod and Branti to patronage contracting are not necessarily bad for government. More careful contracting decisions will generally result in terms more favorable to the government. See M. JohNSToN, supra note 4, at 21-22.

1so Those government entities that engage most extensively in patronage contracting are likely to put forth this inefficiency argument most fervently. Where it is blatantly obvious that political affiliation is the primary motive for contracting decisions, the government entity will indeed be subjected to considerable litigation. But this is precisely the situation where contractors need the strongest protection. All the government entity need do in order to minimize the costs to it from providing contractors with protection under Elrod and Branti is to use procedures that eliminate political considerations from the decisionmaking process. Adoption of such procedures should, in turn, minimize the potential for frivolous suits by disappointed contractors. $C f$. Illinois State Employees Union v. Lewis, 473 F.2d 561, 575-76 (7th Cir. 1972) (rejecting, prior to Elrod, the argument that the administrative costs to the state from extending first amendment protection in the employment context required that protection be denied), cert. denied, 410 U.S. 928, and cert. denied, 410 U.S. 943 (1973). 
tracting appears both obvious and analytically compelled. Nonetheless, the Seventh and Eighth Circuit Courts of Appeals declined to extend this protection and avoided constitutional balancing under a strict scrutiny standard by relying instead upon a perceived distinction between contractors and employees as the basis for their decisions. ${ }^{151}$

It is odd for courts of appeals to rely on formalistic distinctions such as that between employees and independent contractors without having examined whether there is a constitutional justification for the distinction in the first place. ${ }^{152}$ This is particularly so in an area in which the Supreme Court has already rejected the use of formal categories. ${ }^{153}$ Moreover, strict adherence to this distinction appears puzzling in light of the extent to which a functional analysis such as that in Part II of this comment reveals it to be inappropriate. Finally, it is notable that, despite the obvious problems with relying on a distinction between employees and independent contractors in this context, seven judges ${ }^{154}$ on three panels from two courts of appeals representing a broad range of political ideologies have unanimously declined to apply Elrod and

152 The courts took the Supreme Court at its word when it said it was concerned solely with the "dismissal of public employees for partisan reasons," Branti, 445 U.S. at 513 n.7 (emphasis added); Elrod, 427 U.S. at 353 (plurality opinion), 375 (Stewart, J., concurring). See LaFalce v. Houston, 712 F.2d 292, 295 (7th Cir. 1983), cert. denied, 104 S. Ct. 712 (1984); Sweeney v. Bond, 669 F.2d 542, 545 (8th Cir.), cert. denied, 103 S. Ct. 174 (1982).

182 The courts in Sweeny v. Bond, 669 F.2d 542 (8th Cir. 1982), cert. denied, 103 S. Ct. 174 (1982), and Fox \& Co. v. Schoemehl, 671 F.2d 303 (8th Cir. 1982), simply applied the distinction without discussion. See supra notes 59-64 and accompanying text. The court in LaFalce v. Houston, 712 F.2d 292 (7th Cir. 1983), cert. denied, 104 S. Ct. 712 (1984), did consider some reasons for the distinction, see supra notes 65-72 and accompanying text, but it never tied its analysis directly to the policies behind the first amendment. Moreover, the analysis it employed, ad hoc balancing, is at odds with the strict scrutiny normally applied to content-based restrictions on speech. See supra note 116 and accompanying text. If the distinction between employees and independent contractors were well-established in constitutional jurisprudence, this lack of analysis would be unexceptionable; the distinction however has generally been deemed irrelevant to constitutional law questions, see supra note 7 . The distinction appears all the more artificial in this context, since the scope of the constitutional right would depend on state law definitions, and thus vary with the law of each jurisdiction.

15s The Court in Branti rejected reliance on the formal categories of "policymaking" and "confidential" positions in determining the limits of the first amendment prohibition of patronage. Instead, the Court required the more difficult, but functionally more accurate, inquiry into whether the job is one for which "party affiliation is an appropriate requirement." 445 U.S. at 518.

104 Judges Ross, Stephenson, and Howard were on the panel in Sweeney v. Bond, 669 F.2d 542 (8th Cir.), cert. denied, $103 \mathrm{~S}$. Ct. 174 (1982). Judges Ross and Stephenson were again on the the panel in Fox \& Co. v. Schoemehl, 671 F.2d 303 (8th Cir. 1982), along with Judge Bright. The panel in LaFalce v. Houston, 712 F.2d 292 (7th Cir. 1983), cert. denied, 104 S. Ct. 712 (1984), consisted of Judges Posner, Cudahy, and Rosenn. 
Branti in a situation to which they would seem almost inevitably to extend. ${ }^{185}$ The contrast between the analytic similarity of patronage contracting and employment and the almost perverse disparity in the judicial responses they invoke calls for a closer, second look at the problem of patronage and its relation to the first amendment generally. ${ }^{156}$ This investigation reveals a larger, more fundamental conflict that might explain the unwillingness of the courts of appeals to extend Elrod and Branti beyond their narrow holdings even where the extension is logically compelled.

Patronage contracting is only one of many means by which political parties induce support. ${ }^{167}$ Others include rewarding one section of the city that heavily supported a victorious mayoral candidate by improving city services at the expense of a less cooperative ward, or rewarding an interest group's support by pushing for legislation favorable to that group. The problem is that the line between what is "mere patronage" and what is a legitimate part of

16s It is not a sufficient explanation to argue that in both Elrod and Branti the Supreme Court narrowed its holding to patronage employment, see Branti, 445 U.S. at 513 n.7; Elrod, 427 U.S. at 353 (plurality opinion), 375 (Stewart, J., concurring). In those cases, the Court quite properly decided no more than was necessary to resolve the case before it. The care with which the Court emphasized the limits of what it actually decided should indeed be taken as an indication that the Court did not intend that its ruling be facilely extended to other contexts. Yet, by the same token, the explicit narrowness of the Court's holding does not give rise to a negative inference that the rationale of Elrod and Branti cannot be extended beyond patronage employment. Rather, it appears more likely that the Court was inviting lower courts to consider the wisdom of extending the Elrod and Branti rationales, while reserving its own judgment for the future when the possible ramifications of such an extension would have been more fully aired in the lower courts. Insofar as this is an accurate reading of the Court's intention in explicitly circumscribing its holdings in Elrod and Branti, the courts of appeals, with the possible exception of the Seventh Circuit in LaFalce, have declined to accept the Supreme Court's invitation.

${ }^{158}$ Most of the controversy in this area has concentrated on the role of patronage in the two-party system, with speculation on the possibility that the demise of patronage will lead to the demise of political parties. See Schoen, supra note 85, at 86-101; Comment, Patronage and the First Amendment After Elrod v. Burns, 78 Colum. L. REv. 468, 478 (1978); supra notes 128-34 and accompanying text. As the ensuing analysis demonstrates, this focus is misplaced since it only hides the more fundamental issue of the inherent conflict between the first amendment and interest group politics. See infra notes 157-67 and accompanying text.

167 The Cook County Sheriff's practice of dismissing employees on a partisan basis is but one form of the general practice of political patronage. The practice also includes placing loyal supporters in government jobs that may or may not have been made available by political discharges. Nonofficeholders may be the beneficiaries of lucrative government contracts for highway construction, buildings, and supplies. Favored wards may receive improved public services. Members of the judiciary may even engage in the practice through the appointment of receiverships, trusteeships, and refereeships. Although political patronage comprises a broad range of activities, we are here concerned only with the constitutionality of dismissing public employees for partisan reasons.

Elrod, 427 U.S. at 353. 
the democratic process quickly becomes difficult both to perceive and to draw. One of the basic elements of the democratic process is the inducement the elected official has to improve conditions for the public in order to gain support (by vote or otherwise) for reelection. Because society consists of numerous subgroups with conflicting and competing concerns, this process inevitably entails seeking support from some groups at the expense of others. In return for political support, the elected official responds to the desires of his supporters. Viewed in this light, Elrod and Branti simply invalidated a narrow form of interest group politics, ${ }^{158}$ because patronage employment is really only interest group politics on an individual level. $A$ 's dismissal from his government job, to make room for $B$ to be hired as a reward for $B$ 's support, is the functional equivalent on an individual level of a congressman voting for a bill to reward interest group $B$ for its political support at the expense of interest group $A$ that opposed the bill and did not support the congressman.

Elrod and Branti do not compel the conclusion that all interest group politics is unconstitutional under the first amendment. Such an assertion is an obvious overstatement. ${ }^{159}$ Nonetheless, there is a conflict inherent in the principles that underlie the first amendment and those that animate interest group politics. When the conflict takes the form of political practices that are inconsistent with the rights of particular groups or individuals, the Court has not hesitated to step in to protect that group by striking down

268 "Interest group" is used broadly here to include not only narrow, special-interest groups, but also any other group organized for the advancement of its political views, including national political parties.

158 Certain aspects of the system may well prove to be unconstitutional. There is a school of thought, akin to civil republicanism, that would strike down as unconstitutional legislative preferences that merely respond to private interests rather than implementing "public values." In the view of this school, legislation or government action in favor of private groups is permissible only to further a public value; naked preferences in favor of a private interest group are illegitimate. See J. Mansbridge, Beyond Adversary Democracy (1979); Michelman, Politics and Values or What's Really Wrong with Rationality Review?, 13 Creighton L. REv. 487, 506-10 (1979); Sunstein, Deregulation and the Hard-Look Doctrine, 1983 Sup. CT. REv. 177, 183; Sunstein, Public Values, Private Interests, and the Equal Protection Clause, 1982 Sur. CT. REv. 127.

On the other side, however, are those who assert that interest group politics is a legitimate and vital element of the democratic process, enabling more effective political action in a pluralistic society. See, e.g., R. Dahl, Dilemmas of Pluralist Democracy (1982); R. PosNER, Economic ANALYsis of LAW 405-15 (2d ed. 1977); Becker, A Theory of Competition Among Pressure Groups for Political Influence, 98 Q.J. Econ. 371 (1983); Linde, Due Process of Lawmaking, 55 Neb. L. Rev. 197 (1976); Posner, Economics, Politics, and the Reading of Statutes and the Constitution, 49 U. CHI. L. REv. 263 (1982). For an attack on the pluralist position, see T. Spragens, The Irony of Liberal Reason 301-10 (1981). 
the law. ${ }^{160}$ When, however, the conflict produces challenges to the political structures that produce those results, the Court-while not refraining absolutely from acting ${ }^{\mathbf{1 6 1}}$ _has been considerably more restrained. ${ }^{162}$

Patronage is simply a form of financing the political parties that represent the citizenry. ${ }^{163}$ It is perhaps neither the wisest nor the most efficient system for doing so; ${ }^{164}$ nonetheless, it is a wellestablished ${ }^{165}$ part of the interest-group mechanism of political decisionmaking. ${ }^{186}$ The reluctance of the courts of appeals to extend Elrod and Branti beyond their narrowest holdings despite the fact that the logic and rationales of the decisions clearly suggest a broader scope is thus quite understandable. Unfortunately, the courts of appeals have failed to articulate the reasons for their reluctance, and have instead sought to draw a line between the practices invalidated in Elrod and Branti and the rest of the patronage system. The purpose of this comment has been to show that there is no principled way to do so. So long as Elrod and Branti remain

180 See, e.g., NAACP v. Alabama ex rel. Patterson, 357 U.S. 449 (1958) (invalidating state attempt to compel disclosure of association's membership list as impermissible abridgement of freedom of association); Strauder v. West Va., 100 U.S. 303 (1880) (invalidating state law permitting only white males to serve as jurors).

${ }_{162}$ See, e.g., Washington v. Seattle School Dist. No. 1, 458 U.S. 457 (1982) (invalidating statewide initiative which restricted ability of local school boards to institute mandatory busing plans); Powell v. McCormack, 395 U.S. 486 (1969) (holding Congress limited to requirements prescribed in the Constitution when judging the qualifications of its members); Reynolds v. Sims, 377 U.S. 533 (1964) (holding malapportioned legislative districts unconstitutional under the equal protection clause).

${ }_{102}$ See, e.g., Crawford v. Board of Educ., 458 U.S. 527 (1982) (upholding state constitutional amendment that overruled judicial determination that de facto school segregation was unlawful); Mobile v. Bolden, 446 U.S. 55 (1980) (upholding city commission at-large electoral system against equal protection challenge); Luther v. Borden, 48 U.S. (7 How.) 1 (1849) (holding the determination of the legitimacy of a state government to be a question for Congress and the President, not the courts, to decide).

${ }_{163}$ See, e.g., F. SorAUf, supra note 4, at 309-10; supra note 104 and accompanying text.

164 See M. Johnston, supra note 4, at 62-65; F. Soraur, supra note 4, at 320-24.

${ }^{205}$ See supra note 5 and accompanying text.

16s See supra notes $157-58$ and accompanying text.

${ }^{167}$ The Court's decisions in Elrod and Branti can be justified under traditional rationales. Footnote four to the Court's opinion in United States v. Carolene Prods. Co., 304 U.S. 144, 152 n.4 (1938), suggests that the Court will closely scrutinize government action that affects those for whom, as a practical matter, the political process has failed and who are thus effectively and structurally incapable of obtaining a political remedy. Legislatures are unlikely to eliminate patronage completely since the major political parties have a vested interest in maintaining the system. Although the dominant party will benefit more from the system at any given time, the other party may want to preserve the system so that it can enjoy those benefits if and when it becomes dominant. The victims, present or prospective public employees or contractors and minor parties, are unlikely to be able to band together 
good law, ${ }^{167}$ the lower courts are obliged to apply them to patronage contracting.

\section{Conclusion}

By refusing to extend Elrod and Branti to situations involving public contractors, the Seventh and Eighth Circuit Courts of Appeals have imposed an artificial and formalistic limitation on the scope of those decisions. A comparison of the first amendment and government interests at issue in patronage employment and patronage contracting demonstrates both that this limitation does not withstand analysis and that the rationale of Elrod and Branti carries over to patronage contracting. Yet Elrod and Branti, like all decisions by courts that strike at the structure of the political system, raise questions about the institutional role of the Court itself. Indeed, it may well be that someday the Court may wish to reconsider those decisions. In the meantime, however, they remain good law and ought to be given their natural force. Therefore, patronage contracting, like patronage employment, should be protected by the first amendment.

Thomas G. Dagger

to gain enough political clout to command a majority of the legislature's support, particularly since any attempt to do so would amount to biting the hand that feeds them. The occasional reform arises not out of any concern for the first amendment rights of those involved, but rather out of public reaction to the abuses and corruption often associated with patronage. See Elrod, 427 U.S. at 379 (Powell, J., dissenting); supra note 4. Thus, there are built-in limitations to obtaining a comprehensive legislative ban on patronage. As one commentator has cautioned,

Citizens and courts should be chary of efforts by government officials to control the very electoral system which is the primary check on their power. Few prospects are so antithetical to the notion of rule by the people as that of a temporary majority entrenching itself by cleverly manipulating the system through which the voters, in theory, can register their dissatisfaction by choosing a new leadership.

L. TriBE, supra note 111, § 13-18, at 774 . 